University of Rhode Island

DigitalCommons@URI

Open Access Master's Theses

1980

\title{
AN ANALYSIS OF UNSUCCESSFUL PROGRAM OUTCOME AMONG JOB TRAINING CLIENTS
}

Madeline J. Klein

University of Rhode Island

Follow this and additional works at: https://digitalcommons.uri.edu/theses

\section{Recommended Citation}

Klein, Madeline J., "AN ANALYSIS OF UNSUCCESSFUL PROGRAM OUTCOME AMONG JOB TRAINING CLIENTS" (1980). Open Access Master's Theses. Paper 486.

https://digitalcommons.uri.edu/theses/486

This Thesis is brought to you for free and open access by DigitalCommons@URI. It has been accepted for inclusion in Open Access Master's Theses by an authorized administrator of DigitalCommons@URI. For more information, please contact digitalcommons-group@uri.edu. 
AN ANALYSIS OF UNSUCCESSFUL PROGRAM OUTCOME

AMONG JOB TRAINING CLIENTS

BY

MADELINE J. KLEIN

A THESIS PROJECT SUBMITTED IN PARTIAL FULFILLMENT OF THE REQUIREMENTS FOR THE DEGREE OF MASTER OF COMMUNITY PLANNING

UNIVERSITY OF RHODE ISLAND 1980 


\section{MASTER OF COMMUNITY PLANNING THESIS PROJECT \\ OF}

MADELINE J. KLEIN

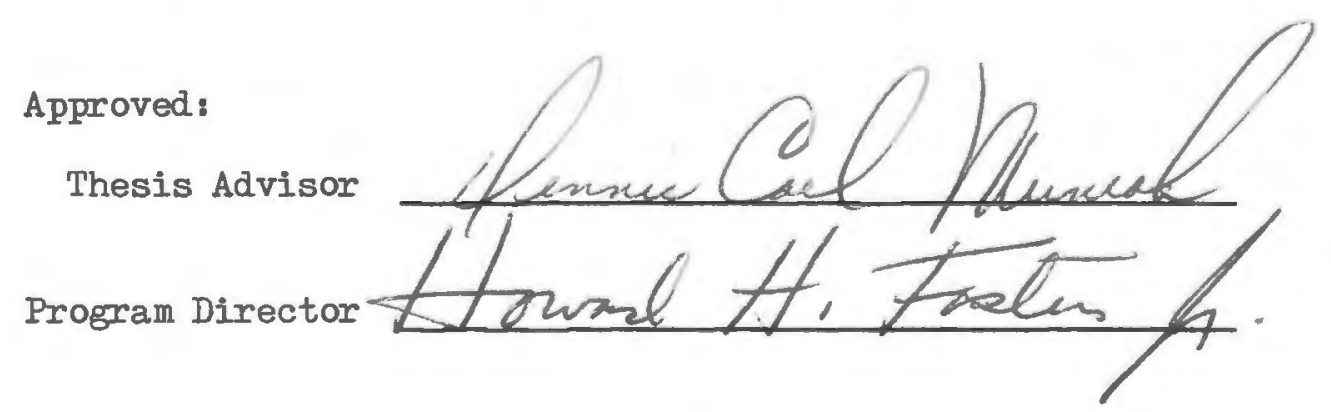

UNIVERSITY OF RHODE ISLAND

1980 


\section{ACKNOW LEDGMENT}

I would like to express my warmest

gratitude to Bernie Beaudreau, who gave

me information, encouragement, and help

in thinking through this analysis. 
CONTENTS

ACKNOWLEDGEMENTS _-

LIST OF TABLES -

INTRODUCTION

A CONTEXT: THE NEED FOR JOB TRAINING -............. 1

Chapter

I. THE SETTING: JOB PREPARATION AT THE OPPORTUNITIES INDUSTRIALILATION CENTER

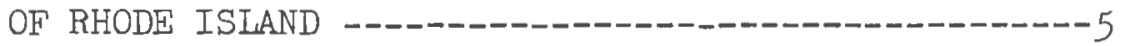

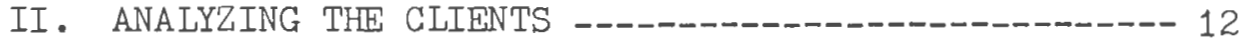

III. CHARACTERISTICS OF PROGRAM PARTICIPANTS AND THEIR RELATION WITH PROGRAM OUTCOME - -

IV. REASONS GIVEN FOR DROPPING OUT-_............. 42

V. SUMMARY AND CONCLUSIONS _._.

APPENDIX -

BIBLIOGRAPHY -._. 62 


\section{LIST OF TABIES}

Table

Page

1. Program Outcomes For Population-_-

2. Sex Compared with Program Outcome --

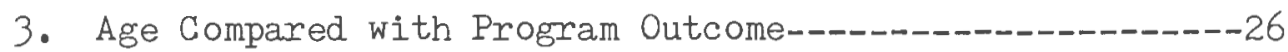

4A. Program Outcome Compared with Years of Education Completed -

4B. Program Outcome Compared with Education Level in Major Kinds of Training-_..._.

5A. Program Outcomes Compared with Ethnic Group and Sex - 29

5B. Program Outcome Compared with Ethnic Group and Age -........ 31

6A. Program Outcome Compared with Family

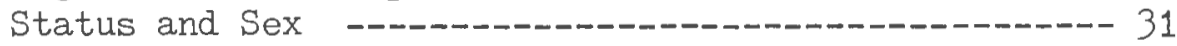

6B. Program Outcome Compared with Family Status, Ethnic Group, and Sex -........-.

7. Program Outcome Compared with Economic Status and Selected Family Status_-_._-_._._._._.-. 34

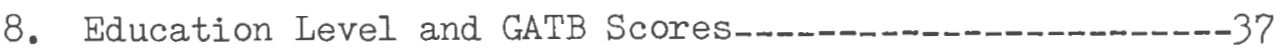

9. GATB Scores and Ethnic Group-_._- 38

10. Program Outcome Compared with Types of Instruction-----41 


\section{INTRODUCTION}

\section{A CONTEXT: THE NEED FOR JOB TRAINING}

The purpose of this paper is to examine the failure of some clients in a job training program to complete the program and to be placed in jobs. The paper addresses two principal questions: who drops out, and why? Before the analysis begins, however, one must set the failure to achieve a successful program outcome in the context of the basic goals of job training。

The problem of structural unemployment among the disadvantaged divides into two basic issues. There is a lack of demand for minorities, the poor, the uneducated, and the unskilled as workers. The disadvantaged, who are, by definition, poor, uneducated, unskilled, and disproportionately from minority groups, offer an overabundant labor supply to this unwilling market. Where the needs of the demand side and the qualifications of the supply side begin to approach one another, a third difficulty arises - matching supply (workers) with demand (jobs).

Public job training programs, such as those implemented under the Gomprehensive Employment and Training Act (CETA), are not a panacea. They are not designed to cure the demand-side pathologies of the labor market; other measures, such as Affirmative Action legislation and tax incentive policies, must serve to remedy institutional discrimination. Job training can and does deal with the supply side and matching problems。 
Public job training concentrates on human resource development. The underlying assumption is that certain segments of the population suffer disproportionately from the problems of unemployment and poverty; research indicates that employers tend to favor persons who are white, not economically disadvantaged, of prime working age, and who have a post-high school education. ${ }^{1}$ The disadvantaged, meanwhile, have a hard time competing in the job market even during times of rapid economic growth; $^{2}$ for minorities and teenagers, and for unskilled laborers, for example, there is "no such thing as a tight labor market." 3 Many of these workers lack the elementary skills to find even entry-level jobs。 Others are employed in dead-end jobs that offer neither upward mobility, nor satisfaction, nor wages decent enough to pull them out of poverty.

With the disadvantaged as its target group, CETA focuses on giving its trainees the ability to compete more successfully for employment. Its clients must learn not only actual job skills, but also accessory behavior and information necessary to enhance their employability。 Again, this does not mean that there will be a job waiting for each client after training. It does mean that clients will have a better chance of finding and keeping jobs that do exist, even when they are competing with applicants with more advantages.

$1_{\text {William Mirengoff and Lester Rindler, CETA: Manpower Programs }}$ Under Local Control (Washington, D.C.: National Academy of Sciences, 1978), p. 235 .

$2_{\text {Ibid. , p.1. }}$

3Charles C. Holt et al, "Manpower Policies to Reduce Inflation and Unemployment," Manpower Programs in the Policy Mix, ed. Lloyd Ulman

(Baltimore: The Johns Hopkins University Press, 1973), p. 76. 
CETA operates several kinds of employment programs, including Public Service Employment (PSE) and Work Experience (WE), which create subsidized employment in the public sector, and on-the-job training (OJT). A major type of training run under CETA auspices is classroom training, which together with support services, will be the concern of this paper.

Classroom training is one of the most obvious solutions to improving the employability of the disadvantaged, who need pre-employment help to obtain positions requiring even low skill levels. Equally obvious is the fact that, without some formal linkage with the demand side of the labor market, it is an exercise in futility. Classroom training must of course prepare its clients for the kinds of jobs which do exist in the local market.

One of the potential pitfalls of this objective is the quality of many available jobs. Often the jobs which are most readily available, such as retail and other service occupations and low skilled factory jobs, require the shortest, simplest and least expensive training, but also offer the least opportunity for long-term advancement, wages, and satisfaction. In the Providence area, for example, the labor market provides ample opportunity for factory jobs, particularly in the jewelry industry, with wages that axe among the lowest in the United States.1 CETA administrations may be tempted to train clients for these positions to achieve the objective of a high level of placement at low cost. In the meantime, occupations which require more training, but which yield greater benefits in the long run, are neglected.

Classroom training programs can try to balance the desire for job placement with constraints on time and money spent on training by

1 Providence Journal, July 27, 1978, p.A3. 
preparing clients for entry-level jobs. Once initially placed, the client is left to upgrade his or her skills through the same on-thejob channels as other employees.

The type of training institution has proven to be an important factor in goal achievement. Over the history of employment planning, experimentation has shown that different people profit from different kinds of settings. Traditional vocational education institutions with traditional approaches are usually less suited to serving the special needs of the disadvantaged than are skills centers, ${ }^{1}$ which are better able to provide such services as counseling, remedial education, and job development, as well as an atmosphere of security. Unfortunately, these less-established centers may suffer shortages of funds and facilities, and may"stigmatize their enrollees and isolate them from the training mainstream"2.

However, the use of intermediate organizations for training, job development, and placement of groups with special problems in the labor market is also an important way to involve private firms which would otherwise ignore them. Many businesses that are willing to hire the disadvantaged are reluctant or unable to deal with the skills training, red tape, and support services that these trainees need. The intermediary provides the workers without the headaches. 3

Prime examples of this kind of intermediate organization are the Opportunities Industrialization Centers of America, Inc.

1Sar A. Levitan, Garth I. Mangum, and Ray Marshall, Human Resources and Labor Markets (New York: Harper and Row, 1976), p. 349.

I Ibid. , p. 350 .

3 The Research and Policy Committee of the Committee for Economic Development, Jobs for the Hard-to Employ-New Directions for a PublicPrivate Partnership (New York: Committee for Economic Development,1978, ). 44 . 


\title{
CHAPTER I
}

\author{
THE SETTING: JOB PREPARATION AT THE \\ OPPORTUNITIES INDUSTRIALIZATION GENTER \\ OF RHODE ISLAND, INC.
}

The Opportunities Industrialization Center of Rhode Island (OIC) is one of about 150 independent affiliates which operate as a nonprofit corporation under the umbrella of OIC of America. Its most basic goal is to improve the quality of life of two overlapping client groups: minorities, and the economically disadvantaged. Although its principal thrust is employment training and job placement for both adult and youth target populations, it also provides other services, such as counseling and instruction in English as a second language, in an effort to serve the "whole" client.

The local OIC depends heavily on its relationship with the local administration of CETA, the Comprehensive Employment and Training Act, which supplied over 80 per cent of its 1978 program funds of $\$ 1,750,000$. (Other funding in 1978 came from the Rhode Island Jif partment of Vocational Education; Rhode Island Governor's Justice Commission; United States Office of Juvenile Justice and Delinquency Prevention; United Way of Southeastern New England; and other sources.) As a contractor with CETA for job training programs, the agency receives moneys originating with the U.S. Department of Labor, and channeled through the City of Providence, and the State of Rhode Island excluding Providence ("balance of state"), which have been designated as "prime sponsors." 
A prime sponsor is a legal entity - usually a government or a consortium of governments - judged capable of effectively administering programs and funds under the CETA act, and given considerable power to design programs and regulate participation at the local level.

Each job training course delegated to OIC by CETA comes under a separate "performance contract。" This means that courses must meet certain performance standards to enable OIC to qualify for new contracts. CETA standards require that $60 \%$ of all participants who start in training programs (not just those who finish training) be placed in training-related jobs.1 However, this rather rigorous formula is apparently flexible enough to allow re-contracting when the contractor comes respectably close: OIC's average training-related placement rate in $1978-1979$ was $58.5 \%$.

\section{Adult Programs}

OIC administers a number of programs for adults and teenagers. Of interesthere are those serving the adult target population, which center on job training and placement. The assumption is that by pursuing the goal of better jobs for minorities and the economically and socially disadvantaged, the agency can best help them to improve the overall quality of their lives.

OIC adopts the supply-side strategy that has been discussed in the introduction. Three tactics help to implement this strategy. The agency provides its clients with usable job skills, with job placement services, and with counseling and other support services.

1However, rules permit OIC to replace any students who drop out in the first two weeks of training. This calls for rapid decisions on terminations during this period; it is not a time for cajoling and second chances. 
Although CETA legislation permits subcontractors to conduct various kinds of training and employment activities, including classroom training, OJT, WE, and PSE programs, OIC adult programs are primarily classroom training activities.

1)Providing Usable Skills

As one might expect in a vocational training agency trying to meet performance standards, adult training programs are directed towards giving participants usable skills which will enable them to get training-related (TR) jobs once they have completed the program. Glearly, therefore, individual job training programs must be preceded by an accurate assessment of the local labor market to determine present and future needs of employers in the area. OIC's analysis uses data as it is available, drawing on three major sources. Existing employment studies by such agencies as CETA and the Department of Employment Security provide general indicators of demand occupations. Specific employer studies, such as surveys of employers' projections in particular occupations, provide more complete information as to the number and nature of the jobs in demand for the immediate future. Finally, the experience of the placement staff strongly influences programming.

Current programs train workers in over a dozen occupational categories. For purposes of program analysis in this paper, these were grouped into four major classifications. The first, office occupations, includes clerk general office, fiscal operations, office helper, office occupations, automated business machines, and miscellaneous office procedures; the second, machine trades, includes machine set-up operator, machinist, machine operator, screw machine operator, 


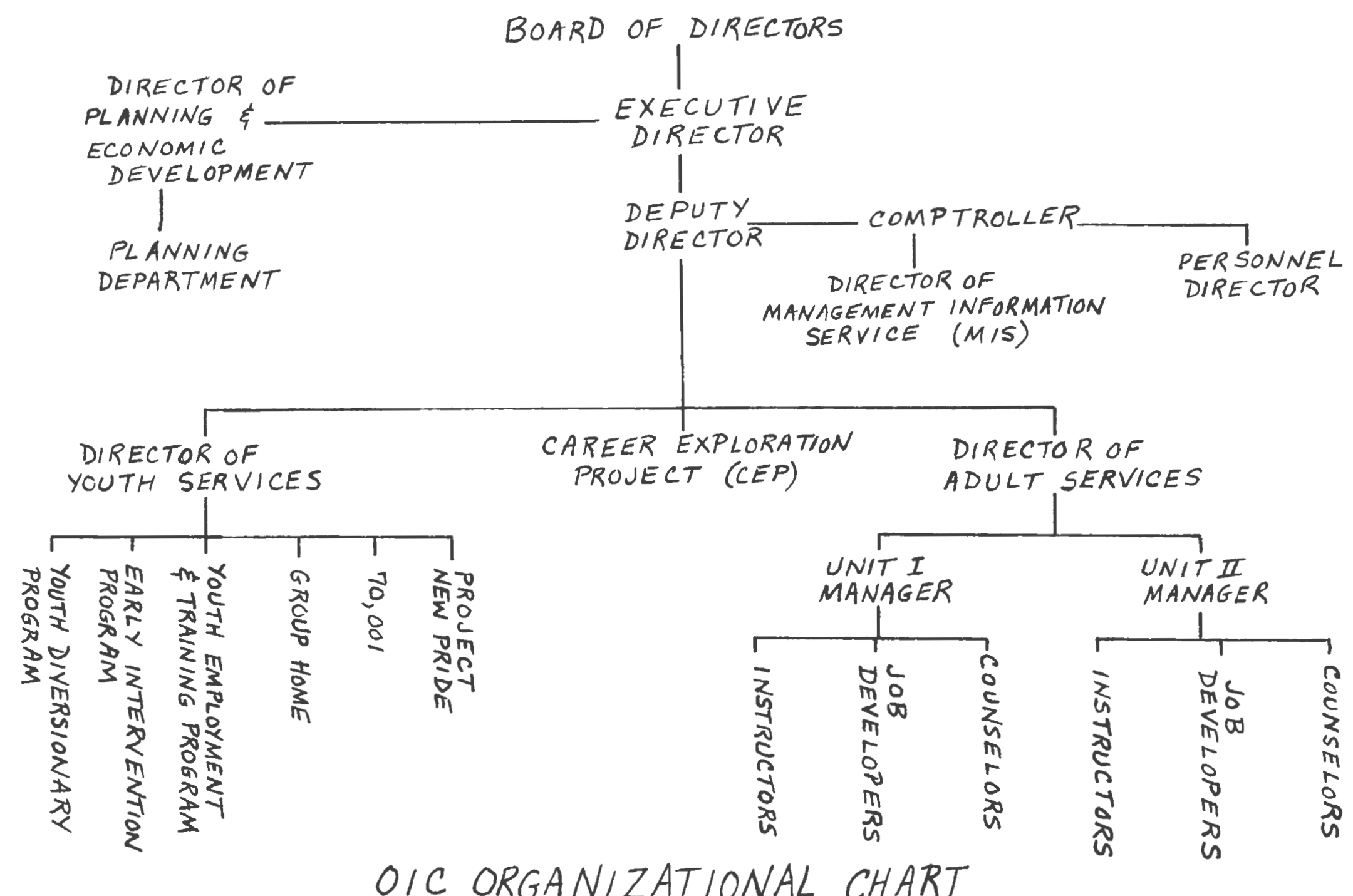


auto body repair, and welding; the third is offset printing and drafting; and the fourth is nurse's assistant. ${ }^{1}$ The courses include several for trainees with language difficulties, who had additional instruction in English as a second language.

Each client enrolls in a twelve-to-twenty-week training program designed to develop the skills needed to land an entry level job upon completion. CETA pays each enrollee minimum wage for actual hours of attendance. During fiscal year 1978-79, 445 adults were enrolled in classroom training.

2) Job Development and Placement

During training, each student is assigned to a job developer for assistance in job placement. Job developers have the twofold responsibility of helping students to become job-ready, and of finding them suitable jobs. They participate in orientation, teach classes in such aspects of employment as realistic expectations of entry-level jobs, job search, and responsibilities and rights of the employee, and meet with students individually。 As each training program nears its end, the job developers try to find the trainees viable, adequately-paying jobs, by "selling" potential employers on a classful of newly-trained students, or on the special qualifications of individuals. It is important that the relationship between job developers and employers be a trusting one. Every effort is made to match the individual with the particular job. This process is overseen by the unit magager (see organizational chart), who is responsible for insuring the required $60 \%$ training-related placement in his or her unit.

1 Other courses, such as boatbuilding, are not analyzed in this paper because they were under the jurisdiction of the Balance of State CETA. Data examined here is from the Providence CETA programs Nursing has been discontinued because jobs in the field typically pay very low wages。 
Despite the performance requirements, a number of students are also placed in non-training-related positions. For example, of clients trained for Providence GETA in fiscal years 1977 and 1978, $62 \%$ were placed in jobs overall, but only $50 \%$ found training related jobs. Given OIC's goal of serving minorities, successful job placement must struggle with discrimination as a barrier to employment. Smaller percentages of black and Hispanic than of white enrollees are typically placed in jobs.

\section{3) Support Services}

While vocational skills themselves are the center of OIC's offerings for adults, other qualifications are often needed to bolster a client's employability. Counseling is one important support service extended to all clients. Each participant is assigned to a unit counselor during the training period. The counselor's job is to aid the trainee is two principal ways. He or she intervenes in situations threatening the trainee's ability to stay in the program - for example, in problems such as illness in the trainee's family, or eviction usually by referring the client to an agency or person specializing in such problems. Second, he/she works on the trainee's attitude, often following notification by the classroom instructor, to help solve such problems as poor attendance or disruptive behavior. In addition, the counselor should work with the trainee on "employability development planning," to assess his/her abilities, experience, and employment goals and package a suitable arrangement of training and support services。 To give further help in total job preparation, the job developer may also coach program graduates in how to prepare effective resumes, interview successfully, and make a generally favorable impression on employers. Such behavior techniques may be reinforced 
within the training program; the clerical classes, for instance, enforce a dress code for participants.

Although a certain amount of training in substantive behavior is probably helpful, some studies (e.g., Salipante and Goodman, 19761) seem to suggest that pure "attitudinal" training has little effect on job performance; actual skills training is far more valuable. Although potential clients would often benefit from trainingrelated education (TRE), such as remedial reading instruction, OIC currently meets this need only minimally。 Its one-hour-per-day TRE schedule cannot effectively make up for a very poor reading ability, for example. As a result of the lack of remedial reading and math services, OIC, at the present time, is only able to serve clients who are at least functionally literate, and quite often, who have a minimum of a high school diploma or equivalency. OIC is presently attempting to extend its services in the basic education pre-vocational training area.

In recent years, a growing number of Hispanic and Asian immigrants has moved to Rhode Island. For foreign language-speaking clients, the agency runs a program combining vocational training with instruction in English as a second language (ESL).

1Paul Salipante, Jr。 and Paul Goodman,"Training, Counseling, and Retention of the Hard-Core Unemployed," Journal of Applied Psychology Vol. 61 (February, 1976),pp.1-11。 


\section{CHAPTER II}

\section{ANALYZING THE GLIENTS}

Overview

As a framework for examining the factors which lead clients to drop out of training programs, the Reiner, Reimer, and Reiner method of client analysis ${ }^{1}$ contributes useful insights into the process by which the legally eligible clients filter down to those who are actual beneficiaries of the program. The method traces clients through several major steps. The preliminary "client population," or those who are legally eligible to participate in the program, diminishes to the "clients" who are actual users of the program. These two groups may differ in character as well as in number, because of 1) "selection standards," or policies by which the administering agency chooses to eliminate certain eligible people while it targets others; and 2) "standards of service," operating procedures by which the agency indirectly prevents or discourages certain groups from participating. Finally, the number of actual clients dwindles to a still smaller group of persons who "effectively benefit" from the program。

\section{Client Population}

Federal CETA legislation sets up the eligibility criteria for participants in each CETA program. To be eligible for a Title IIB program - under which most OIC adult training programs operate -

1Janet S. Reiner, Everett Reimer, and Thomas Reiner, "Client Analysis and the Planning of Public Policies," Urban Planning and Social Policy, ed. Bernard J. Frieden and Robert Morris, (New York: Basic Books, Inc., 1968), pp.377-95. 
an applicant must be "economically disadvantaged" and "unemployed, underemployed, or an in-school youth:" 1 (The regulations define each of these terms at length.) Until 1979, the legislation merely required program participants to be economically disadvantaged or unemployed, underemployed, etc. These new criteria instantly narrow the client population, eliminating a large number of middle-class applicants, and restricting eligibility to those most in need.

Selection Standards and Actual Users

CETA processes all intake for OIC $^{\circ}$ s adult programs. Each applicant must fill out the appropriate forms; take the three-hour General Aptitude Test Battery (GATB): and see a counselor about the test results before ever coming to OIC. The CETA office rates candidates on their test performances, using the scores to screen out a large number. This process has been called an inappropriate use of the GATB, which does not measure other qualities, such as motivation, and which tends to measure learned rather than innate ability. Lacking a better tool for screening and directing candidates, however, CETA and OIC intake continues to rely on these tests.

Other implicit "standards of service" constraints probably influence this stage of the filtering process. For instance, a potential client must first know about the CETA program in order to apply for it, and must get him/herself to the downtown CETA office on two or three separate occasions merely to have a chance of acceptance.

1U.S. Department of Labor, Employment and Training Administration, "Comprehensive Employment and Training Act: Proposed Rules For Programs Under Titles I,II,VI, and VII of the Act," in Federal Register, Vol.44, no.14, January 19, 1979, p.4370. 
While some applicants know of OIC programs through OIC's advertising and occasional recruiting drives, a majority are familiar with CETA itself. This is due partly to the popularity of the stipends it pays its program participants.

Once accepted by CEIA and directed to OIC, the applicant must be accepted by OIC. Keeping in mind the required $60 \%$ performance standard, the agency tries to ensure success by using literacy level as a principal entrance criterion. Candidates for clerical training should read at about the eleventh grade level or above, candidates for other instruction at an eighth or ninth grade level.

Clearly, the actual client group in OIC $^{\circ} \mathrm{s}$ program is greatly reduced during the intake process。 While legal eligibility criteria have directed the CETA programs to the most needy, both CETA and OIC divert this goal by choosing only the most promising of the disadvantaged to enter their programs。

This is a dilemma faced by all vocational training programs under CETA and its predecessors. Agencies committed to both their clients and their own existence must cope with a "seemingly paradoxical emphasis on job placement, while (manpower policy) urges the enrollment of the least employable."1

Effectively Benefited Clients

Within the immediate scope of the program, these are clients who are actually placed in jobs, or about $60 \%$ of the participants who began training. Most of the trainees who do not find jobs do not finish the training program; that is, for a variety of reasons, and despite available support services, they drop out in the instructional 
phase. A number of others complete training but drop out during the placement phase before finding a job, and still another group cannot be placed within the thirty days allowed by CETA. These phenomena, then, again cut drastically the number of clients who actually benefit from the programs.

The idea of effective benefits requires a longer look, however. The Department of Labor counts a smaller number of benefited clients. Its definition includes only those who have found training related jobs.

But beyond placement rates, within the more basic, longer term goal of job training, how "effective"are the benefits? Their quality can be measured further by asking how long graduates keep their jobs, and how much they earn, as well as how soon and how far they are promoted beyond their initial entry-level placements. For example, the average starting wage for clients trained for Providence CETA in fiscal years 1977 and 1978 was $\$ 3.16$ of all the people placed, 85\% were still working in the same job after 30 days, 68\% after 60 days, and $62 \%$ after 180 days. If, as in this case, $62 \%$ of enrollees are placed in jobs, and $62 \%$ of these placed graduates are still on the job after 180 days, this means that only about $38 \%$ of the original participants were in the same jobs after the follow-up period. However, no information is available on the job mobility of graduates, job retention after the six month follow-up period, or the progress a graduate may make after leaving his or her original job. Such data would be essential to an assessment of lasting economic benefits. Furthermore, many trainees may acquire more intangible benefits, such as self-confidence or knowledge of thelabor market. Exploration of these issues is beyond 
the scope of this paper.

This client analysis method has given an overview of the progress of clients through the training program, and has suggested a few factors contributing to the elimination of some clients along the way. The next chapters will examine the transition from "clients" to "effectively benefited" clients。

\section{CLIENT ANALYSIS}

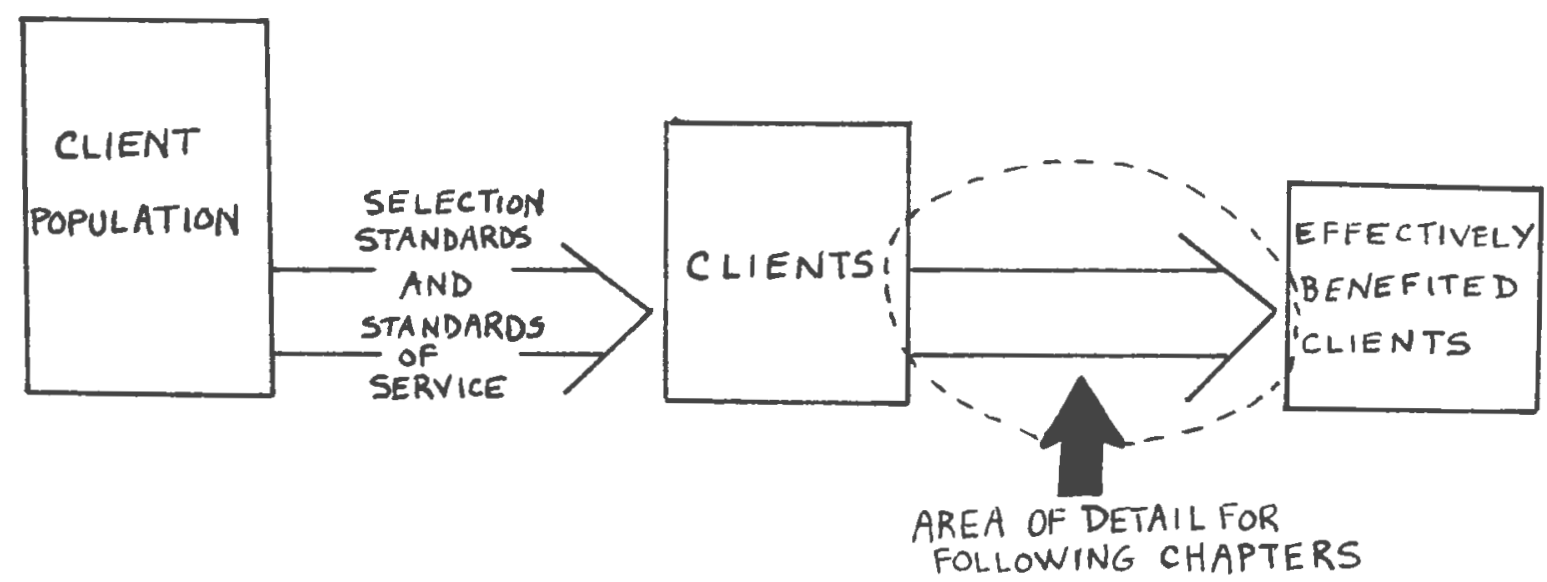

Focusing On Dropouts

From the beginning to end of the classroom training and job placement process, then, there are many pitfalls。 A complete program evaluation would examine the effectiveness of each program component- intake, instruction, counseling, job development, placement, and follow-up - in detail.

This paper, however, concentrates on the clients themselves and their interaction with the program. Certain facts are taken as "givens." 
There is no discussion of $\mathrm{CETA}^{\circ} \mathrm{s}$ eligibility requirements, for instance, or of the likelihood that a particular kind of occupational training will lead to job mobility。 The paper will discuss the very localized factors which contribute to success or failure for various segments of the client group。 A program's effectiveness means more than numbers. We must know just who benefits most and who gets least from the program. Why drops out, and why? Whom is it difficult to place? Different sub-populations may exhibit different patterns of training outcomes. Identifying such subgroups would give agency personnel a head start in taking special measures with those clients with potential difficulties. Often such findings may merely confirm what the staff already knows more informally from its own daily experience; but they may also help to fine-tune such observations.

Chapter III contains a detailed statistical analysis of client characteristics and their correlation with clients" interaction with the program and program outcome. Files from Providence CETA ${ }^{1}$ provided information on a number of demographic and socioeconomic variables for 389 participants: sex, age, education level, ethnic group, family status, family size, economic status, labor status, weeks unemployed, and wages earned before coming to CETA. They also supplied data on the applicants ${ }^{\circ}$ GATB scores, and on certain aspects of his or her performance in the program: How long he or she attended; which training module he or she enrolled in; whether or not the trainee completed training satisfactorily; why he or she terminated; and wage earned after placement.

\footnotetext{
1 Providence CETA Prime Sponsor, Management Information System,
} October, 1979. 
There were, naturally, some obstacles in using this information. Certain data, such as job history and previous wages, was often either missing or misleading. Other data was unclear; the number of a trainee's dependents, for example, gave no indication of the presence of very young children at home. As a result, such information is not considered in this analysis. Most of the data, however, provided a valuable basis for comparing and testing numerous subgroups within the client group.

Chapter III also looks at aptitude test scores and the type of course in which trainees participated as predictive tools. It is important to establish the value - or lack of it - of the GATB as an intake method. The training itself is a major program component, controlled with minimal constraints by the agency itself, and thus accessible for change.

Chapter IV takes a more informal look at some of the specific problems that cause students to drop out of the program. These might be obstacles in the client's personal life, such as a need for child care, or legal trouble, or there might be dissatisfaction with particular aspects of the program or agency itself, such as a shortage of facilities and equipment, or inadequate attention from a counselor。

The information from this section comes from OIC ${ }^{\circ} \mathrm{s}$ files on graduates and from a survey of a small number of nonpositive terminees. Because the data from both sources is unstandardized and sketchy, a formal analysis in inappropriate. Without trying to draw any hard conclusions, however, one can discover some interesting and helpful insights into the factors that lead to unsuccessful program outcomes. 
Finally, Chapter $V$ will summarize the major findings of the paper, and will explore the reasons underlying the phenomenon of dropping out. 
CHAPTER III

\section{CHARACTERISTICS OF PROGRAM PARTICIPANTS}

AND THEIR RELATION WITH PROGRAM OUTCOME

\section{PROFILE OF CLIENTS}

A general profile of the population served by OIC's training programs emerges from the data collected by Providence CETA. This data provides information on 389 clients who terminated training in fiscal year 1979. Although, as has been noted, certain kinds of information was too incomplete to be useful, other indicators supply a helpful demographic and socioeconomic picture of enrollees.

Men and women are fairly evenly represented, with $46 \%$ of enrollees male and 54\% female. Predictably, however, sex usually determines the type of job a person trains for. Students in classes in nursing and in office skills were almost exclusively female, while those training for machine trades, including welding and auto body repair, were almost all men. Only in classes for printing and drafting, where about two thirds of the trainees were men and one third women, was there any real mixture of the sexes. (Although beyond the scope of this paper, it is worth noting that the customary wages for machinists are considerably higher than those of office workers and nurses aides.)

Designed to give particular attention to the employment problems of minorities, OIC enrolled more than $57 \%$ of its clients from these groups. About 37\% of the population was black, 15\% Hispanic, 
21

5\% Asian, and just over 1\% American Indian. 1 The remainder and largest group, about $43 \%$, was white.

Although the ages of participants ranged from 17 to 60 , the great majority of OIC's clients, over 76\%, were between 19 and 24 。 The median age was 23.7. Because only $8 \%$ of the trainees were over 40, the problems associated with "older" wurkers are rare in the agency. Age distribution was comparable among ethnic groups.

A look at education completed by clients before enrolling in the program shows that about one third had less than a high school education, and two thirds were high school graduates. The largest single segment, 52\%, had finished high school but had gone no further in school. 13\% had attended some college, and about 3\% more were college graduates. The ethnic subpopulations divided somewhat differently, however; whereas $28 \%$ of whites and $27 \%$ of blacks did not have a high school diploma, fully half of the Hispanics and $42 \%$ of the Asians had not completed high school.2

A participant's family status could fall into one of three categories. He or she could be the head of a household containing one or more other members; a member other than head of such a household; or the single person in a one-person household. $38 \%$ of this group were "heads" of household, 17\% "members" of a household, and 45\% lived as "single member" households. Cross-comparisons show that a person's family status is slightly associated with sex - 10\% more of the women than of the men were in the head of household

1 Because of the small numbers of Asians (19) and American Indians (5), these groups are usually not analyzed here as separate segments of the population. The continuing growth of the Asian minority will no doubt make future analysis both easier and more necessary.

2 Interestingly, a higher percentage (19\%) of Asians than of any other group had had at least some higher education. Presumably their disadvantages in the labor market often spring from the problems of living in a foreign culture, as much as from lack of training. 
and member-of-household groups, and $20 \%$ fewer of the women than of the men lived alone. A much clearer connection appears between family status and age, however, with the percentages of household heads rising with age, members declining with age, and singles maintaining a more even level throughout age groups (Figure 1). This evidence suggests that family "member" status more often reflects young people living with parents than spouses (wives) adding to the family's income, although by definition no "members" are primary wage earners.

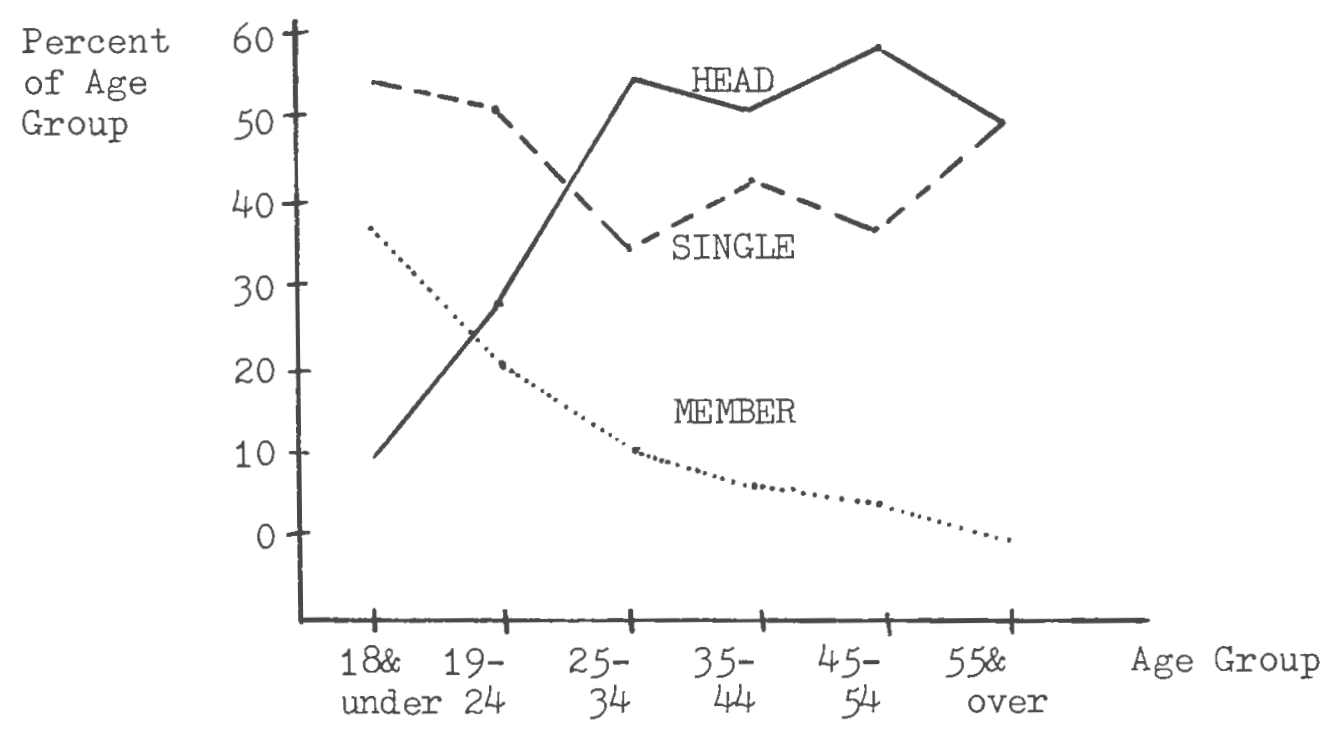

FIGURE 1: FAMILY STATUS IN DIFFERENT AGE GROUPS 
An individual's family status was also likely to vary according to his or her ethnic group. While the proportion of family "members" stayed fairly constant across ethnic lines, the proportion of heads of household changed conspicuously: $29 \%$ of the whites, $45 \%$ of the blacks, and $52 \%$ of the Hispanics headed a household. The number of singles was considerably higher for whites (55\%) than for blacks (37\%) or Hispanics (32\%).

Grouped by their economic status, one fourth of the members of the population received public assistance, the vast majority of them (89\%) under Aid to Families with Dependent Children (AFDC), the remainder from such programs as Supplemental Security Income (SSI). Since most AFDC funds go to households headed by a single parent, and the single parent is generally the mother, a lopsided majority of the welfare recipients were women. The proportion of trainees getting assistance was slightly higher for blacks than for whites or Hispanics。

EFFECT OF CLIENT CHARACTERISTICS ON PROGRAM OUTCOME

The central question, of course, is how these characteristics affect a person's success or failure in the training program, and ultimately in his or her placement in a job. Although, as previous discussion indicates, there are a number of limits on job training as a cure for the unemployment of the disadvantaged, it is obvious that a client gets few of the possible benefits if he or she drops out of the program。

The decisions on significant relationships among characteristics expressed in this section are all based, except where otherwise 
indicated, on chi-square tests on contingency tables; the computed chi-square values and probability of dependence of the variables are presented along with each table。

Program outcome refers to the way a student concludes his or her contact with the program in either the instruction or the placement phase, whether or not the student completes training. There are three major categories of program outcome.

The first, "positive termination," includes job placement by the OIC staff after participation in a training program (whether or not the student completed the entire classroom module), called indirect placement;"1 self-placement, in which the trainee finds him/herself a job; and a trainee's return to school or enrollment in another kind of vocational training. A second group is "nonpositive terminations", and includes those who drop out because of problems in health, pregnancy, or family care, moving from the area, expulsion from the program ("administrative separation"), or the catch-all "refused to continue" for unspecified reasons. Although most dropouts do not complete training, some quit after completion, but before placement. The third group is composed of clients who successfully complete their classroom training but cannot be placed by OIC personnel; this is also considered "nonpositive termination."

In this entire population, about $60 \%$ of the students finished in positive terminations, almost all in job placements through OIC. OIC could not place another $9 \%$ who finished training. About $31 \%$ of the enrollees ended as nonpositive terminations; of these, 18\% dropped out for health or family care reasons, 13\% moved from the area, 9\%

${ }^{1}$ The term "indirect placement" is used to signify job placement following the intervention of a CETA program, contrasting with "direct placement" by CETA without any participation in a training program. 
were expelled, and over half, 53\%, quit for some other reason (Table 1). $60 \%$ (73) of the dropouts did not finish training, and 40\% (48) dropped out after completion.

TABLE 1

PROGRAM OUTCOMES FOR STUDY POPULATION

\begin{tabular}{|c|c|c|c|}
\hline Positive Terminations: & $\begin{array}{l}(N) \\
(231)\end{array}$ & $\frac{\% \text { of Total }}{60.0}$ & $\frac{\% \text { of Positive Terminations }}{100.0}$ \\
\hline Indirect Placement & $(213)$ & 55.3 & 92.2 \\
\hline Self Placement & 12) & 3.1 & 5.2 \\
\hline Returned to School & 5) & 1.3 & 2.2 \\
\hline Othera & 1) & .3 & .4 \\
\hline $\begin{array}{l}\text { Nonpositive Terminations: } \\
\text { Dropouts: }\end{array}$ & (121) & $\frac{\% \text { of Total }}{31.4}$ & $\frac{\% \text { of Dropouts }}{100.0}$ \\
\hline Refused to Continue & 63) & 16.4 & 52.1 \\
\hline $\begin{array}{l}\text { Health, Pregnancy, } \\
\text { or Family Care }\end{array}$ & 22) & 5.7 & 18.2 \\
\hline Moved from Area & 16) & 4.2 & 13.2 \\
\hline $\begin{array}{l}\text { Administrative } \\
\text { Separation }\end{array}$ & 11) & 2.9 & 9.1 \\
\hline $\begin{array}{l}\text { Other } \\
\text { Nonpositive Terminations: } \\
\text { Completed Training, Un- } \\
\text { able to Place }\end{array}$ & (9) & 2.3 & $\begin{array}{c}7.4 \\
\% \text { of Unable to Place } \\
100.0\end{array}$ \\
\hline
\end{tabular}

a unspecified
$\mathrm{b}$ can't locate, or other unspecified

Three client characteristics taken alone, age, sex, and years of education completed, appear to have little use as signals of completion or placement problems。

SEX

Sex is apparently not significantly connected with program outcome. A slightly higher proportion of women than of men ended up in a job, and a similar pattern held for enrollees who finished training but could not be placed, while men had a somewhat higher dropout rate than women (Table 2). Still, variations are too small to allow us to conclude that a real relationship exists. 
TABLE 2

SEX COMPARED WITH PROGRAM OUTCOME ${ }^{\mathrm{a}}$

(N) $\frac{\text { Positive Terminations }}{\%} \frac{\text { Dropouts }}{\%} \quad \frac{\text { Unable to Place }}{\%}$

$\begin{array}{llllllll}\text { Male } & (178) & 58.4 & (104) & 35.4 & (63) & 6.2 & (11) \\ \text { Female } & (207) & 60.2 & (127) & 27.5 & (58) & 10.4 & (22)\end{array}$

chi-square $=4.002$

degrees of freedom $=2$

probability of dependence $=.865$ a percents in all

tables read across rows.

AGE

A student's age did not correspond with success or failure in the program, either. Again, the sample data reveals a pattern, but not a significant one. Successful placement dropped as age rose, until a sharp rise in placement in the oldest age bracket, 45 and older, reversed the trend. Dropout rates followed the opposite pattern. The rate of unable-to-place clients climbed slightly for each age group. (Table 3).

\section{TABLE 3}

AGE COMPARED WITH PROGRAM OUTCOME

$\frac{\text { Positive Terminations }}{\%} \frac{\text { Dropouts }}{\%} \frac{\text { Unable to Place }}{\%} \frac{\text { Total }}{(\mathrm{N})}$

$17-18$ years $68.6 \quad(24)$ 19-24 years $62.1 \quad(110)$

25-34 years 56.3

35-44 years 50.0

45 \& over $\quad 65.2$

(67)

(16)

(15)

\section{7}

(9) 5.7

31.1

33.6

37.5

21.7

(55) 6.8

(40) 10.1

(12) 12.5

(5) 13.0

(2)

(4)

(3)

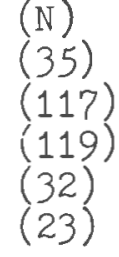

chi-square $=5.520$

probability of dependence $=.299$

degrees of freedom $=8$

\section{EDUCATION}

Finally, the type of termination did not show a significant overall correlation with the amount of education participants had

completed. The lack of correspondance held true whether high school graduates were matched with non-graduates, or clients were compared 
in segments that were broken down further. (Table 4A). However, although education level did not affect program outcome for clients in three kinds of training classes - office occupations, machine trades, and nursing - it was significantly related to outcome in the printing and drafting classes (Table 4B). In this category, 82\% of non-high school graduates dropped and only $9 \%$ were successfully placed, while, of the graduates, $31 \%$ dropped out, and $64 \%$ were placed. In the total population, only one group - those who had some college education, but were not college graduates - displayed any aberration, with a somewhat larger percentage completing training but not being placed. This overall lack of association is particularly noteworthy because it contradicts the finding of two other studies of a variety of CETA programs such as on-the-job-training and vocational education as well as OIC. A study in Providence concluded that, except for college graduates, who had a very high dropout rate, persons with more education were more likely to complete the program, and to be placed。1 Similarly,

TABLE $4 \mathrm{~A}$

PROGRAM OUTCOME COMPARED WITH YEARS OF EDUCATION COMPLETED Positive Termination Dropouts Unable to Place Total(N)

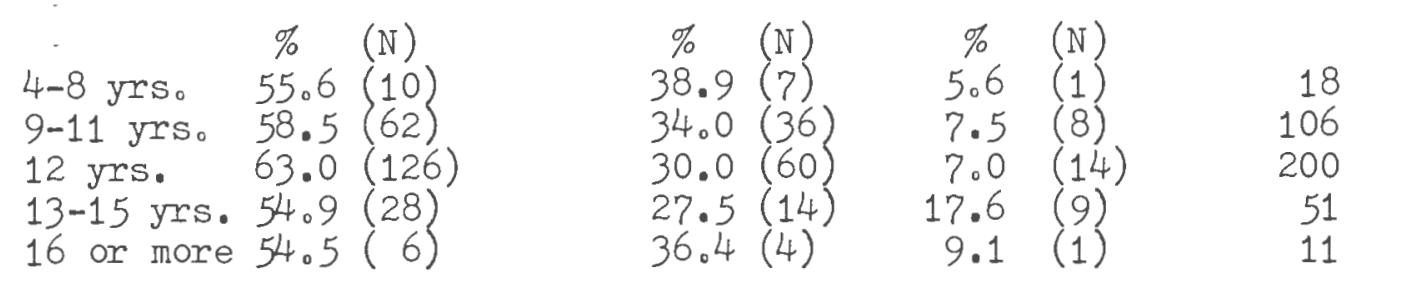

$$
\begin{gathered}
\text { Chi-Square }=7.498 \text { Degrees of Freedom }=8 \\
\text { Probability of dependence }=.516
\end{gathered}
$$

1 Frances E. Kobrin, "Follow-up Evaluation Project" (unpublished interim report for Providence CETA Administration,) January, 1980。 
a study of Boston CETA skill training programs found that high school graduates were more likely to be placed than non-graduates. 1 The discrepancy seems to suggest that the extensive support services and type or quality of classroom instruction offered at OIC generally succeed in correcting the disadvantage of less education. OIC would appear to be well-suited to the needs of these clients.

TABLE 4B

PROGRAM OUTCOME COMPARED WITH EDUCATION LEVEL IN MAJOR KINDS OF TRAINING

\begin{tabular}{|c|c|c|c|c|c|c|c|}
\hline Total: & $\begin{array}{l}\text { Non-H.S. Graduates } \\
\text { H.S. Graduates }\end{array}$ & $\begin{array}{ll}\text { Pos. Term. } & \text { Term } \\
58.1 & (72) \\
61.1 & (160)\end{array}$ & $\begin{array}{l}\frac{\text { Dropol }}{34.7} \\
29.8\end{array}$ & $\begin{array}{l}\text { ts } \\
(43) \\
(78)\end{array}$ & $\begin{array}{r}\text { Unable } \\
7.3 \\
9.2\end{array}$ & $\frac{\text { to Place }}{(9)}$ & $\begin{array}{l}\text { Total } \\
\begin{array}{l}124 \\
262\end{array}\end{array}$ \\
\hline $\begin{array}{l}\text { Office } \\
\text { Occ- } \\
\text { upations }\end{array}$ & $\begin{array}{l}\text { Non-H.S. Graduates } \\
\text { H.S. Graduates }\end{array}$ & $\begin{array}{ll}65.1 & (28) \\
56.7 & (72)\end{array}$ & $\begin{array}{l}18.6 \\
29.1\end{array}$ & $\begin{array}{l}(8) \\
(37)\end{array}$ & $\begin{array}{l}16.3 \\
24.2\end{array}$ & $\begin{array}{l}(7) \\
(18)\end{array}$ & $\begin{array}{r}43 \\
127\end{array}$ \\
\hline $\begin{array}{l}\text { Machine } \\
\text { Trades }\end{array}$ & $\begin{array}{l}\text { Non-H.S. Graduates } \\
\text { H.S. Graduates }\end{array}$ & $\begin{array}{ll}66.0 & (33) \\
64.1 & (41)\end{array}$ & $\begin{array}{l}34.0 \\
32.8\end{array}$ & $\begin{array}{l}(17) \\
(21)\end{array}$ & $\begin{array}{l}0.0 \\
3.1\end{array}$ & $\begin{array}{l}(0) \\
(2)\end{array}$ & $\begin{array}{l}50 \\
64\end{array}$ \\
\hline $\begin{array}{l}\text { Printing } \\
\text { Drafting }\end{array}$ & $\begin{array}{l}\text { Non-H.S. Graduates } \\
\text { H.S. Graduates }\end{array}$ & $\begin{array}{r}9.1 \\
64.3\end{array}$ & $\begin{array}{l}81.8 \\
31.0\end{array}$ & $\begin{array}{l}(9) \\
(13)\end{array}$ & $\begin{array}{l}9.1 \\
4.8\end{array}$ & $\left(\begin{array}{l}1 \\
(2)\end{array}\right.$ & $\begin{array}{l}11 \\
42\end{array}$ \\
\hline Nursing & $\begin{array}{l}\text { Non-H.S. Graduates } \\
\text { H.S. Graduates }\end{array}$ & $\begin{array}{ll}52.6 & (10) \\
72.7 & (16)\end{array}$ & $\begin{array}{l}47.4 \\
27.3\end{array}$ & $\begin{array}{l}(9) \\
(6)\end{array}$ & $\begin{array}{l}0.0 \\
0.0\end{array}$ & $\begin{array}{l}(0) \\
(0)\end{array}$ & $\begin{array}{l}19 \\
22\end{array}$ \\
\hline
\end{tabular}

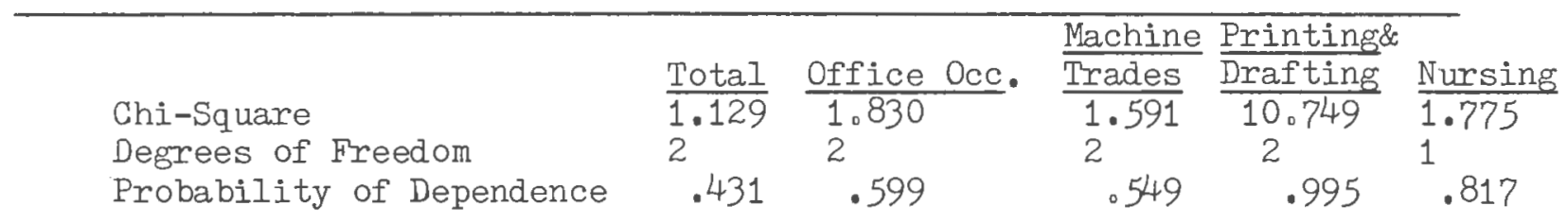

1 Pawan $\mathrm{K}$. Sawhney et al., "Selected Findings of a Follow-up Survey of CETA Title I Institutional Skill Training Programs in Boston," The New England Journal of Business and Economics, V, (Fall, 1978), pp. 77 . 
Other traits, however, seem to flag groups with higher-than average tendencies to drop out of to be difficult to place.

\section{ETHNIC GROUP}

Program outcomes do relate significantly to ethnic group. Blacks were more likely to drop out than whites, and Hispanics dropped out more often than blacks. (Asians had the best record of program success, dropping out only $10 \%$ of the time, with nearly 90\% finding jobs.) (Table 5A). Stated another way, while the dropout rate for blacks (35\%) was close to "average"(31\%) for the population, the rate for whites (26\%) was somewhat lower, and that for Hispanics (46\%) was dramatically higher. On the other hand, very few of those

TABLE 5A

PROGRAM OUTCOME COMPARED WITH ETHNIC GROUP AND SEX

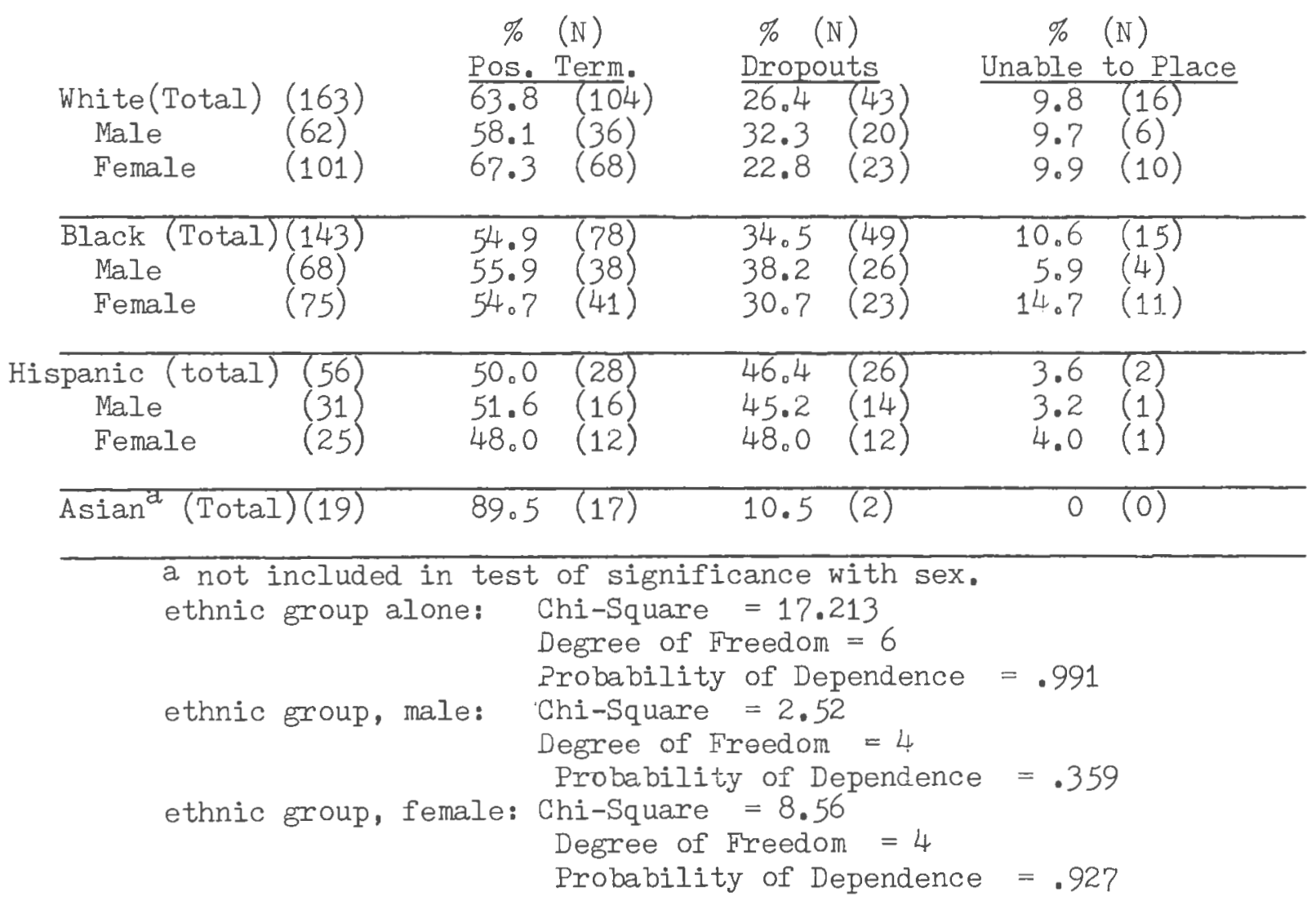


Hispanics who did complete their courses were unable to find jobs (4\%). Still, this was not enough to offset the trend of nonpositive termination; $36 \%$ of the Hispanics did not end up placed in jobs。

Although sex is not a determining factor in quitting the program, it is interesting to note that white females had a very low dropout rate (23\%) as well as overall rate of negative terminations (33\%), and that Hispanic women had the highest dropout rate (48\%) and proportion of negative terminations (52\%). (Table 5A). Similarly, although age alone is not a reliable predictor, when ethnic groups were divided by age brackets, whites showed a marked fluctuation in termination types. Whereas whites 20 and under exhibited a remarkable rate of job placement (88\%), whites in their thirties performed badly, with over half (53\%) quitting and only $40 \%$ ending up with jobs. Whites 40 and over had a hard time finding jobs after satisfactory completion (29\%). Among blacks, however, participants 40 and older had the most success, with over $71 \%$ ending in positive terminations, and only 14\% dropping out. Older Hispanics had less luck, with only one third completing the program successfully. Neither the black nor the Hispanic groups showed significant differences, however (Table 5B).

FAMILY STATUS

Another characteristic with an apparent influence on the quit rate was the individual's position in the family. (Table 6). A test of proportions showed that heads of families dropped out significantly more often than others $(\alpha=.05, z=2.43)$; almost $39 \%$ did so. Apparently it is women who explain the poorer performance 
TABLE 5B

PROGRAM OUTCOME COMPARED WITH ETHNIC GROUP AND AGE

\begin{tabular}{|c|c|c|c|c|c|c|c|c|}
\hline Age & \multicolumn{3}{|c|}{$\begin{array}{c}\text { Positive Term } \\
\%(\mathrm{~N})\end{array}$} & \multicolumn{3}{|c|}{$\begin{array}{l}\text { Dropouts } \\
\%(\mathrm{~N})\end{array}$} & \multicolumn{2}{|c|}{$\begin{array}{c}\text { Unable to Place } \\
\%(N)\end{array}$} \\
\hline $\begin{array}{l}17-20 \\
21-29 \\
30-39 \\
40 \&\end{array}$ & $\begin{array}{l}\text { White } \\
87.5(42) \\
60.3(41) \\
40.0(12) \\
52.9(9)\end{array}$ & $\mid \begin{array}{c}\text { Black } \\
52.5(21) \\
51.4(37) \\
66.7(16) \\
71.4(5)\end{array}$ & $\begin{array}{l}\text { Hispanic } \\
58.3(?) \\
46.4(13 \\
60.0(6) \\
33.3(2)\end{array}$ & $\begin{array}{l}\text { White } \\
10.4(5) \\
27 \cdot 9(19) \\
53.3(16) \\
17.6(3)\end{array}$ & $\left|\begin{array}{l}\text { Black } \\
35.0(14) \\
41.7(30) \\
16.7(4) \\
14.3(1)\end{array}\right|$ & $\mid \begin{array}{l}\text { Hispanid } \\
41.7(5) \\
46.4(13) \\
40.0(4) \\
66.7(4)\end{array}$ & $\begin{array}{l}\text { White Black } \\
2.1(1) \\
11.8(8) \\
6.5 .9(5) \\
6.7(2) \\
29.4(5) \\
14.3(4)\end{array}$ & $\begin{array}{l}\text { ispanic } \\
0(0) \\
7.1(2) \\
0(0) \\
0(0)\end{array}$ \\
\hline
\end{tabular}

white: chi-square $=30.927$

probability of dependence $=.999$

degrees of freedom $=.6$

\section{Hispanic:}

black: chi-square $=7.275$

probability of dependencero $\overline{4}$ degrees of freedom $=6$

chi-square $=3.448$

probability of dependence $=.249$

degrees of freedom $=6$

of this group. Female heads of household - presumably single parents - were

less successful than any of the other subgroups, with $42 \%$ dropping out, and only half succeeding. Men who headed families, on the other hand, had a lower proportion of dropouts (34\%) than men who were family "members" or who lived alone (37\%) (Table 6A).

TABLE 6A

PROGRAM OUTCOME COMPARED WITH FAMILY STATUS AND SEX

Positive

$\frac{\text { Termination }}{\%(\mathrm{~N})} \quad \frac{\text { Dropouts }}{\%(\mathrm{~N})} \quad \frac{\text { Unable to Place }}{\%(\mathrm{~N})} \quad-\frac{\text { Total }}{(\mathrm{N})}$

Female Heads

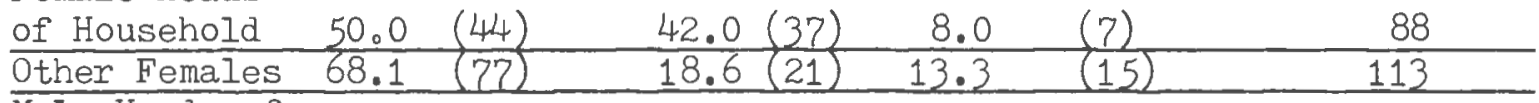

Male Heads of

Household Other Males

$59.3(35)$

$56.4(62)$

$33.9(20)$

6.8

$37.3(41) \quad 6.4$

(4)

110

chi-square $=16.645$, degrees of freedom $=6$, probability of dependence $=.989$

Subdivided by ethnic groups, the percentage of dropouts was slightly higher (43\%) among white heads of families, and considerably higher (59\%)among Hispanics, although among blacks family "heads" 
had the lowest dropout rate (30\%). As in the population as a whole, a larger proportion of women than of men dropped out among both the white and black heads of households. Among "members" of households and people living singly, however, men dropped out more often than women. Hispanics, on the other hand, exhibited the reverse pattern. More than $71 \%$ of the male Hispanic family heads dropped out, compared to $47 \%$ of the female family heads; $24 \%$ of the other Hispanic males, and $50 \%$ of other Hispanic females dropped out. Although the number of Hispanics is too small to produce conclusions about Hispanics in general, and neither the pattern among Hispanics nor that among blacks was satistically significant, these trends should be noted for future study。 (Table 6B).

Economic Status

Economic status also significantly affected success or failure in the OIC programs. Recipients of AFDC or other public assistance left the program in greater numbers (42\%) than trainees who were not on welfare (28\%). One obvious explanation is that welfare recipients can afford to drop out because their payments continue whether or not they are in a training program. ${ }^{1}$ But further investigation of the welfare population brings to light other possible reasons for quitting. Most of these clients, remember, get money under the aegis of AFDC rather than other public assistance programs. Closer examination shows that of the 96 people receiving assistance, 72 (75\%) were female heads of household.

1 Welfare recipients continue to get their normal payments, plus \$30. per week "incentive" pay from CETA while they are in training, rather than the standard CETA stipend. 
TABLE 6B

PROGRAM OUTCOME COMPARED WITH FAMILY STATUS, ETHNIC GROUP, \& SEX

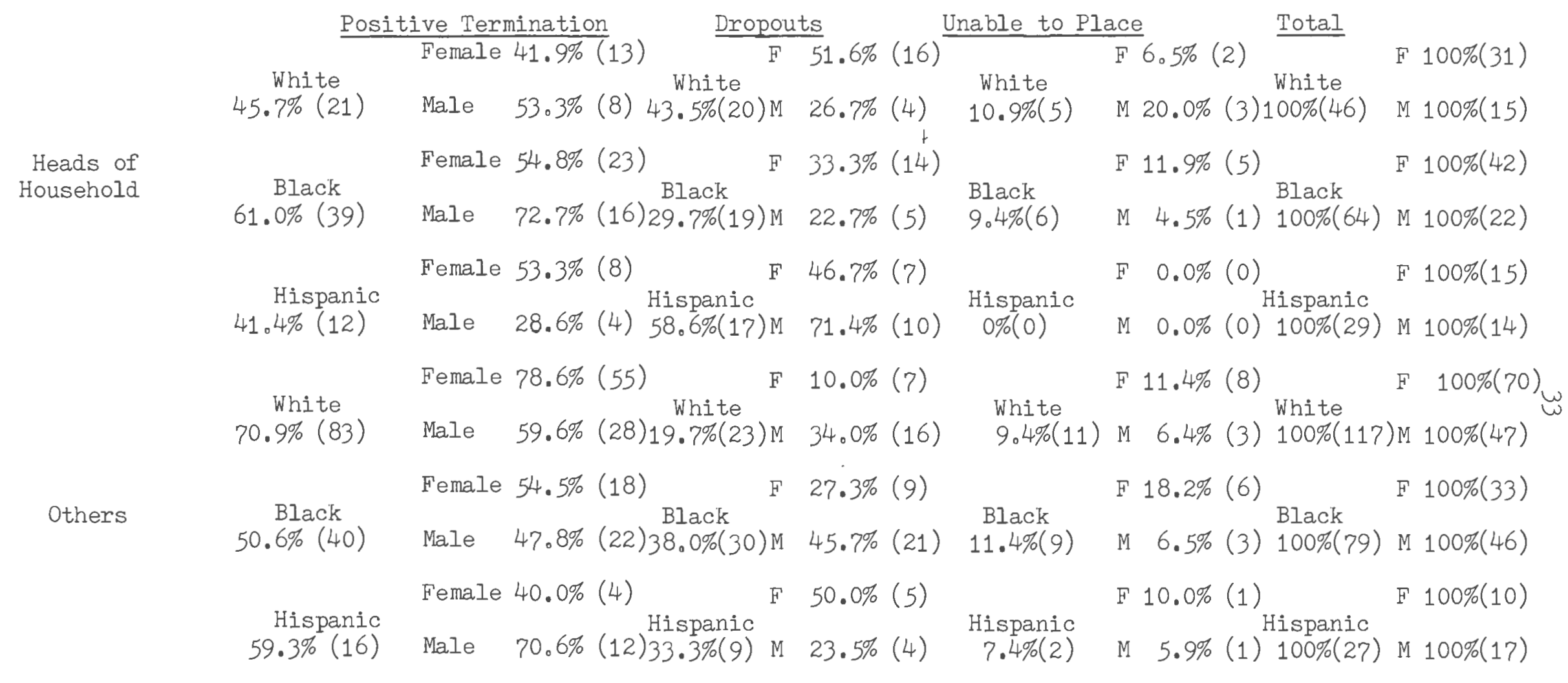

outcome by family status \& ethnic group: chi-square $=24.698$

degrees of freedom $=10$

probability of dependence $=.994$ outcome by family status, ethnic group \& sex: white:

chi-square $=23.446$

degrees of freedom $=6$ probability of dependence $=.999$
Hispanic: black:

chi-square $=8.130$

degrees of freedom 6

probability of dependence $=.771$ degrees of freedom $=6$

probability of dependence $=.839$ 
As we have seen, this group has a stronger tendency to drop out than other groups. In fact, of the 40 welfare recipients who dropped out of the program, $32(80 \%)$ were female heads of household. $44 \%$ of female heads of household on assistance dropped out, while $33 \%$ of the rest of the welfare group did so. Although these numbers are not significant according to a test of proportions $(\alpha=.05, Z=.96)$, they do follow the significant pattern set by the population as a whole, in which $42 \%$ of the female household heads and $29 \%$ of all others left the program. Female heads of families who were not receiving assistance dropped out $29 \%$ of the time; the difference between this group and female family heads on assistance was not significant in a test of proportions $(\alpha=.05, Z=1,13)$. Table 7$)$.

\section{TABLE 7}

PROGRAM OUTCOME COMPARED WITH ECONOMIC STATUS AND SELECTED FAMILY STATUS

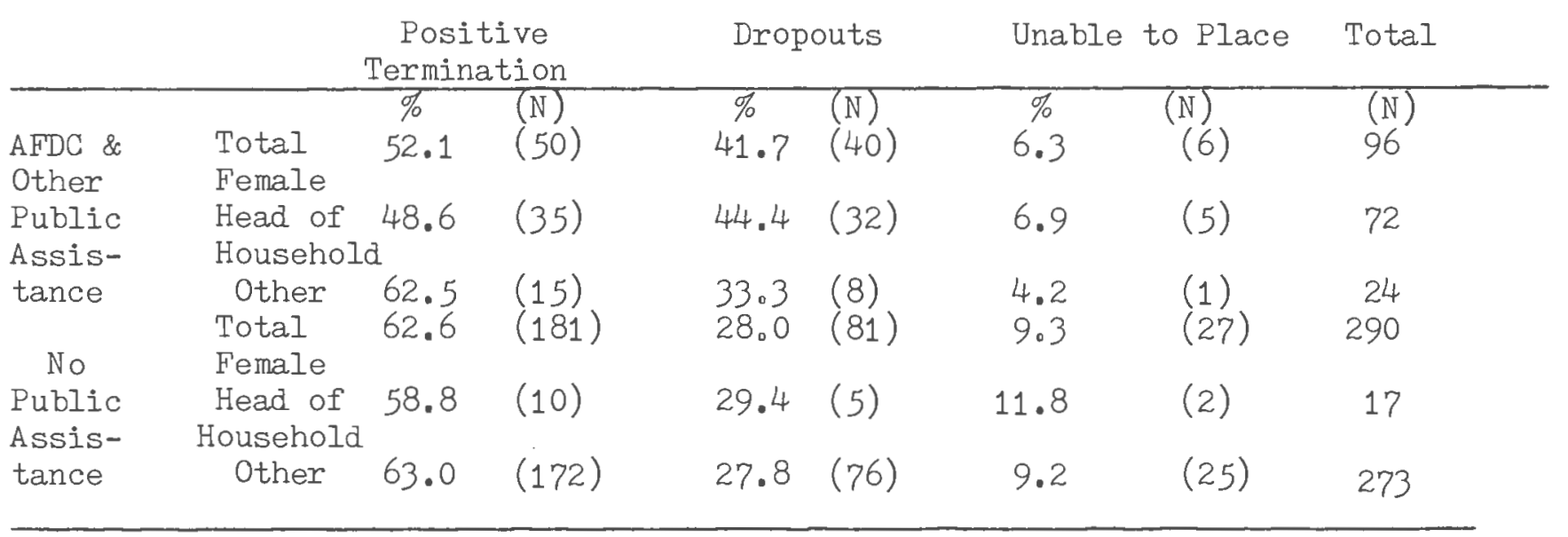

Total: chi-square $=6.405$, Probability of dependence $=.959$ degrees of freedom $=2$

General Aptitude Tests

Besides demographic and socioeconomic information, trainees' GATB scores from the intake phase can be examined for their predictive ability。 
The nine tests are meant to measure the individual's general aptitude, as well as aptitude in verbal, numerical, manual, clerical, and other areas. Certain test scores are selected as indicators of ability to perform well in each kind of training course. For example, high scores in the general, verbal, and numerical aptitude tests are considered necessary for an enrollee in a fiscal operations module, while scores in the general, numerical, spatial, and manual tests are of interest for a student in a machinist class. The individual's relevant scores are compared with minimum scores required in each training area, in an attempt to match aptitude with training; a number of students are permitted to enroll in courses even if they score below the minimum, but are then required to take five additional hours of training-related education (TRE) per week.

Whether the tests truly measure the person's ability in each area, or whether they are a more accurate reflection of education, test-taking ability, and other characteristics, is an important question. Furthermore, the course a person takes is sometimes determined by the classes being offered at the time he or she applies, rather than by aptitude or even preference.

A comparison of the scores for the general, verbal, and numerical aptitude tests with program outcomes shows some correlation between the two. For both the general and the numerical tests, the mean score was significantly higher for those who succeeded in getting jobs than for those who dropped out. 1 Scores on the verbal exam, on the other hand,

1 General: $\alpha=.05, Z=1.80$ Numerical: $\alpha=.05, Z=2.66$ 
showed no significant difference between the means for these two groups. 1 However, the same three aptitude test scores show a strong correlation with two client characteristics, education level and ethnic group.

Not surprisingly, people with more education performed better on the GATB than people with less. While the distribution of scores for both groups clustered in the middle range, in each of these tests, high school graduates' scores were skewed toward the higher levels, while non-graduates" scores were pulled toward the lower end. (Figure 2 gives a typical example.) In the general test, for example, over two-thirds of non-graduates scored below the median, while less than $42 \%$ of the graduates ranked in the bottom half. This grouping was consistent in all three tests (Table 8).

FIGURE 2:

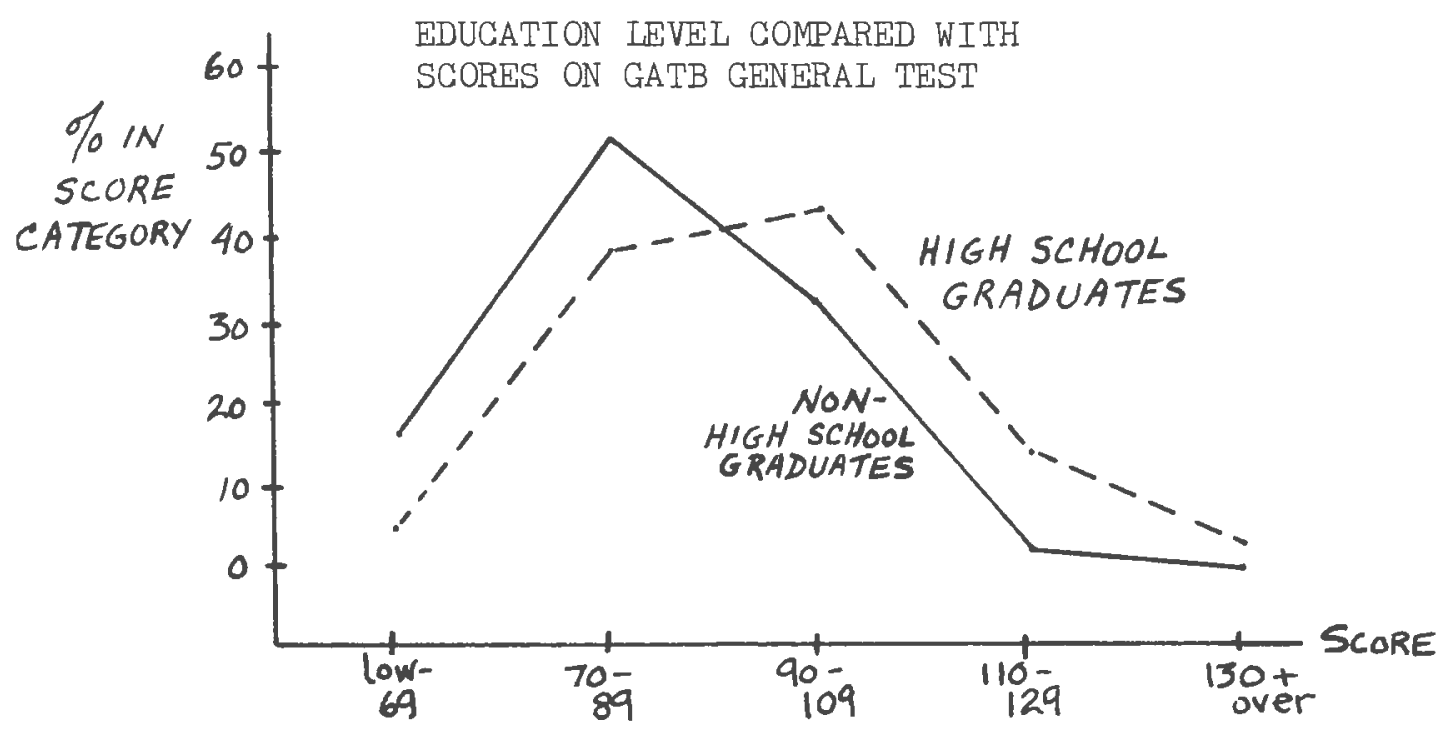

The relationship between test performance and ethnic group was also a significant one. Blacks consistently averaged higher than Hispanics while whites, on the average, far outscored the other two groups. In the test of general aptitude, $29 \%$ of the whites scored below the median,

1 Verbal: $\alpha=.05, Z=1.12$ 
while less than $42 \%$ of the graduates ranked in the bottom half. This grouping was consistent in all three tests (Table 8).

TABLE 8

EDUCATION LEVEL COMPARED WITH GATB SCORES

\begin{tabular}{|c|c|c|c|c|c|c|}
\hline \multirow{2}{*}{$\begin{array}{l}\text { General } \\
\text { (Median= } \\
89.9)\end{array}$} & \multirow[b]{2}{*}{$\begin{array}{l}\text { Non-High } \\
\text { School } \\
\text { Graduate } \\
\text { High } \\
\text { School } \\
\text { Graduate }\end{array}$} & $\frac{\text { Low }-69}{\% \quad(N)}$ & $\frac{70-89}{\%}(\mathrm{~N})$ & $\frac{90-109}{\%}(\mathrm{~N})$ & $\frac{110-129}{\%} \quad(\mathrm{~N})$ & $\frac{130+}{\%}(\mathrm{~N})$ \\
\hline & & $\begin{array}{r}15.7(17) \\
5.6(14)\end{array}$ & $\begin{array}{l}51.9(56) \\
36.1(91)\end{array}$ & $\begin{cases}30.6 & (33) \\
42.5 & (107)\end{cases}$ & $\left\{\begin{array}{cc}1.9 & (2) \\
13.5 & (34)\end{array}\right.$ & $\begin{array}{cc}0 & (0) \\
2.4(6)\end{array}$ \\
\hline $\begin{array}{l}\frac{\text { Verbal }}{(\text { Median }}= \\
91.6)\end{array}$ & $\begin{array}{l}\text { Non-High } \\
\text { School } \\
\text { Graduate } \\
\text { High } \\
\text { School } \\
\text { Graduate }\end{array}$ & $\begin{array}{l}10.2(11) \\
3.2(8)\end{array}$ & $\begin{array}{l}53.7(58) \\
32.7(83)\end{array}$ & $\begin{array}{l}31.5(34) \\
48.0(121)\end{array}$ & $\begin{array}{l}4.6(5) \\
13.9(35)\end{array}$ & $0 \quad(0)$ \\
\hline $\begin{array}{l}\text { Numerical } \\
\text { (Median= } \\
90.9)\end{array}$ & $\begin{array}{l}\text { Non-High } \\
\text { School } \\
\text { Graduate } \\
\text { High } \\
\text { School } \\
\text { Graduate }\end{array}$ & $15.7(17)$ & $\begin{array}{l}45.4(49) \\
34.7(87)\end{array}$ & $\mid \begin{array}{ll}36.1 & (39) \\
44.2 & (111)\end{array}$ & $2.8 \quad(3)$ & $.8 \quad(2)$ \\
\hline & $\begin{array}{l}\text { neral: } \\
\text { hi-square= } \\
\text { egrees of } \\
\text { robability } \\
\text { endence = }\end{array}$ & $\begin{array}{lr}265 & \mathrm{Vez} \\
\text { edom=4 } & \mathrm{d} \\
\mathrm{de}- & \mathrm{p} \\
9 & ]\end{array}$ & $\begin{array}{l}\text { bal: } \\
\text { i-square }=2 \\
\text { grees of } \mathrm{f} \\
\text { obability } \\
\text { endence }=.9\end{array}$ & $\begin{array}{l}8.141 \\
\text { reedom=4 } \\
\text { of de- } \\
99\end{array}$ & $\begin{array}{l}\text { umerical: } \\
\text { chi-square= } \\
\text { degrees of } \\
\text { probability } \\
\text { pendence=. }\end{array}$ & $\begin{array}{l}354 \\
\text { edom }=4 \\
\text { de- }\end{array}$ \\
\hline
\end{tabular}

The relationship between test performance and ethnic group was also a significant one. Blacks consistently averaged higher than Hispanics while whites, on the average, far outscored the other two groups. In the test of general aptitude, $29 \%$ of the whites scored below the median, while $61 \%$ of the blacks, and $73 \%$ of the Hispanics were in the lower half (Table 9). One explanation which immediately presents itself is the unfamiliarity of many Hispanics with English; weak language skills are obviously a formidable obstacle to strong test performance. The fact that Hispanics close 
the gap slightly in the numerical test lends credibility to this thesis. However, since the major difference is between whites and the other two groups, the barrier is clearly larger than a language problem. The GATB appears to test something besides pure occupational aptitude.

TABLE 9

GATB SCORES COMPARED WITH ETHNIC GROUP

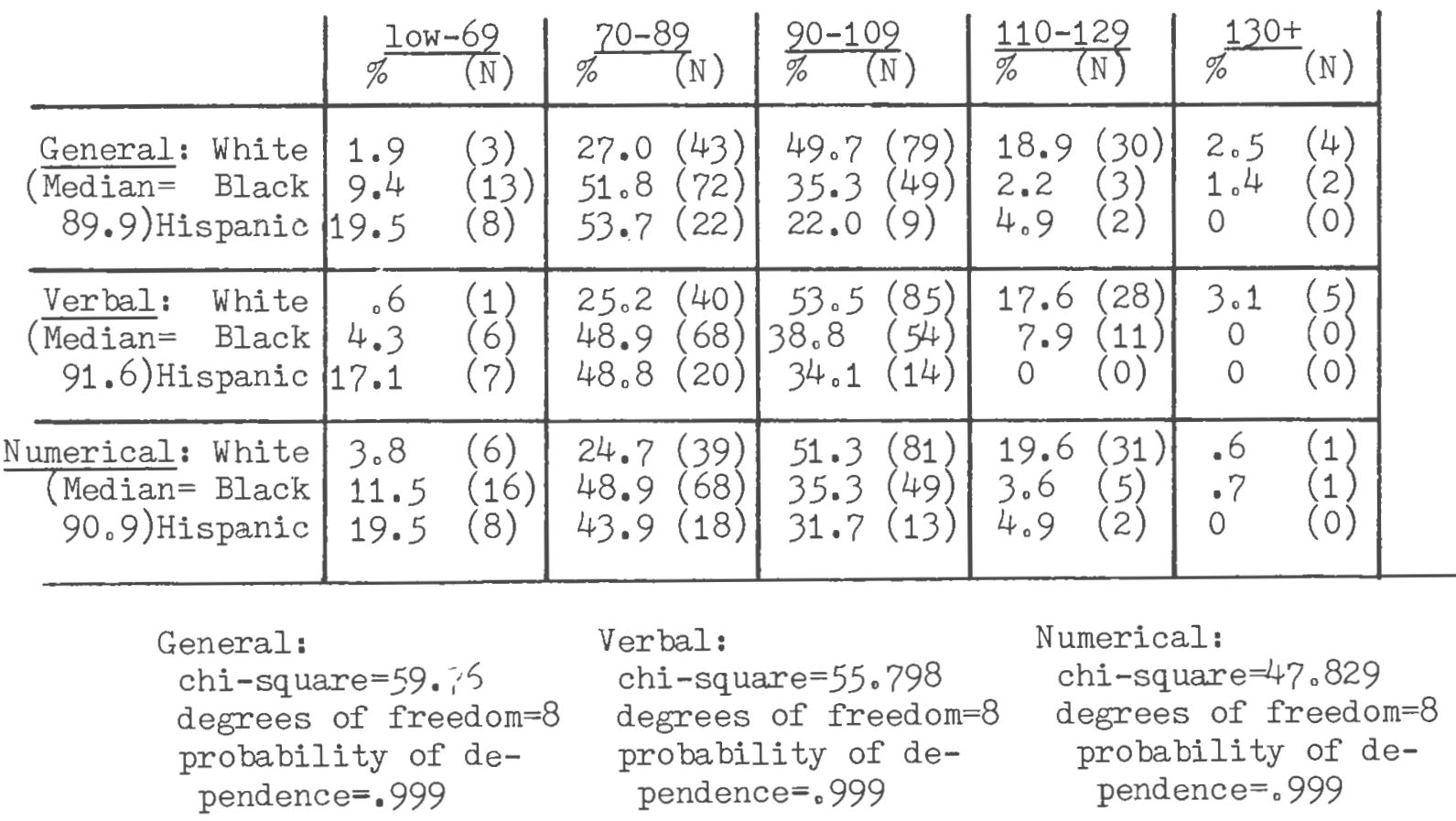

Because certain tests are more important than others in directing a client towards a certain kind of training, it would also be useful to know whether the relevant scores for each type of training module are reliable indicators of program outcome for that category.

Different minimum scores are used as cut-off points for different modules within the four main categores. For instance, a client must score higher in the "verbal" exam to qualify for a class in word processing than to qualify for clerk general office training. Furthermore, despite an overlap, different tests are sometimes used as indicators for different 
modules; for example, candidates for word processing must score well in the general, verbal, clerical, and motor skills tests, while applicants for clerk general office classes are checked for their scores in the general, verbal, clerical, and numerical exams. For this reason, trainees' scores for the indicator tests were roughly compared by the percentages of the scores on pertinent tests, rather than by the absolute scores. Cross-tabulations, and chi-square tests of significance were, again, used in each case.

No significant relationships emerged between the score percentages and program outcome in the office, machinist, and nursing categories. The printing and drafting group, however, presented a different finding. Although a comparison of the "average percentage" of all relevant scores with program success showed no correlation between the two, two of the four individual test scores were significantly related to outcome. In both the numerical and the spatial aptitude tests, trainees who had scored lowest had, by far, the highest proportion of dropouts; $87 \%$ of low scorers on the numerical test, and $62 \%$ of low scorers on the spatial test dropped out. 1 Two previous findings should be recalled here. First, the printing and drafting sector was also the only one in which high school graduates performed significantly better than non-high school graduates. Second, in the entire population, graduates scored significantly higher on the aptitude tests than non-graduates. Taken together, these three observations suggest that the poor performance of low GATB scorers in the printing and drafting sector may reflect the same factors in the training which cause poor

1 Numerical: chi-square-9.493, degrees of freedom=4, probability of dependence $=.950$.

Spatial: chi-square $=9.617$, degrees of freedom $=4$, probability of dependence $=.953$. 
performance among those with less than a high school education.

Type of Training

Another vital angle of investigation is the influence of elements within the OIC program itself. A student contracting for one area of instruction may have a higher probability of success than one in another area.

A clear and significant pattern emerges in the relation of these four contract types with terminations (Table 10). The office occupations group reveals an especially interesting trend. Although the dropout rate here is lower than average $(27 \%)$, the percentage of completers who cannot be placed is decisively higher (almost 15\%) than average; the next highest unable-to-place proportion, in the printing and drafting group, is less than $6 \%$.

The lowest placement rate (52\%), and the highest dropout rate (42\%) appear in the printing and drafting category. There is some evidence of a lack of adequate training equipment for classes in these fields, causing frustration among students, and logically, leading many to quit.

Students in machinist and nursing classes had the most successful outcomes. $65 \%$ of the machinists and $63 \%$ of the nurse ${ }^{\circ} \mathrm{s}$ aides were placed; one third of the machinists, and $37 \%$ of the nurses dropped out; and less than $2 \%$ in machine trades, and none in nursing, could not find jobs after successfully completing the program. 
TABLE 10

TYPE OF INSTRUCTION COMPARED WITH PROGRAM OUTCOME

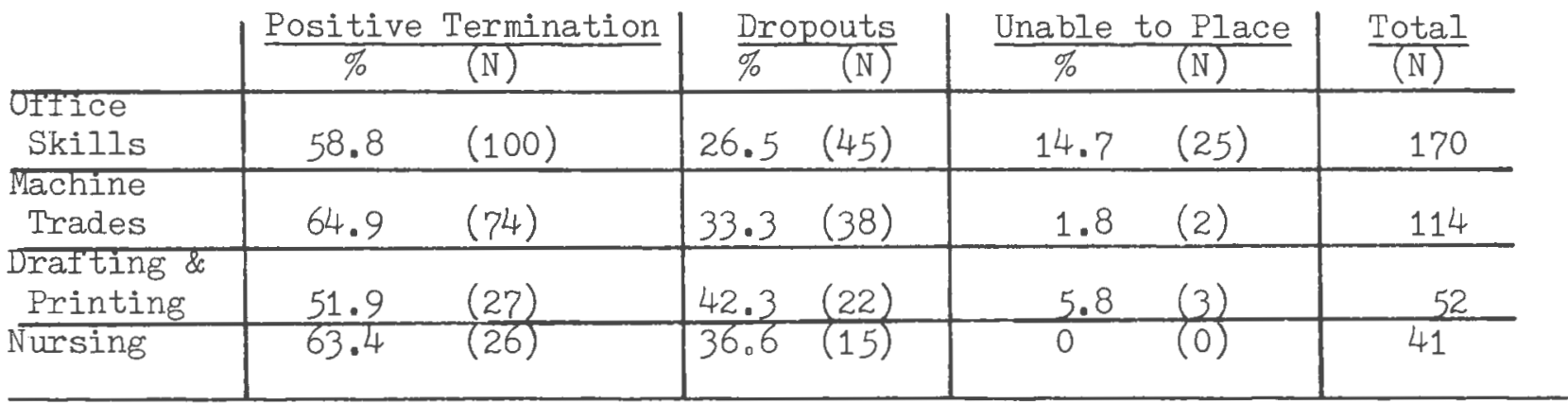

chi-square $=23.653$

degrees of freedom $=6$

probability of dependence $=.999$ 


\section{CHAPTER IV}

REASONS GIVEN FOR DROPPING OUT

The observations discussed in this chapter have been collected from OIC files on 139 terminees under both Providence and balanceof-state CETA contracts, and from a survey of 43 of these ex-participants. As has been mentioned, the nature of the data prevents any formal analysis. Although OIC maintains files on each client, a considerable amount of information is incomplete or unstandardized. The most revealing of this information comes from notes kept by a trainee's counselor, describing his or her performance and problems in the program. Depending on the individual counselor, and the type of the student's problems - or, as is sometimes the case, a lack of conspicuous problems some notes are more instructive than others. In addition, the files usually contain CETA intake information, such as health history and test scores. They may also include autobiographies, goal statements, and reactions to OIC orientation written by students when they enter the program, and evaluations of classroom performance submitted by the instructors.

The surveys (Appendix A), which were administered by telephone, after an initial mail contact, primarily by temporary OIC staff members, encountered two problems. One was the extreme difficulty of contacting clients after they had left the program; many had moved, for example, or could not be reached at the telephone numbers they had given. Secondly, many questions were omitted or not answered completely. 
One should also be aware that missing data may conceal any kind of situation. For instance, when counselors' notes make no mention of problems, this does not necessarily mean that no problems exist. One can only assume that many of the most pressing issues have been expressed.

Warned about these deficiencies, one can still observe some common problems, which fall into two basic areas. The first category is difficulties that the client had as an individual, apart from his or her involvement in the program; this area includes trouble with family care, health, transportation, and other personal issues. The second area concerns the client's difficulties as a program participant, including dissatisfaction with the program or agency, and academic problems. A third section on placement notes typical outcomes in the placement phase.

PERSONAL PROBLEMS

Family Care

OIC does not directly provide child care. In an attempt to promote clients' self-reliance, the agency assists students in learning how to make their own babysitting arrangements, offering extra help in extreme cases. Child care facilities in the community are reported to be adequate.

However, 23 trainees said they had decided to drop out because of problems in caring for their children. The lack of a babysitter or some other child care provision had already led to an excessive number of absences in some cases, complicating the original problem by making the student miss instruction time and violating OIC rules. Frequently the issue of child care arose because of the children's 
health. Some parents might have felt comfortable leaving their children with a babysitter or day care center if they were well, but felt that they must care for them themselves when they were sick. Two questions are left unanswered. First, there is no way of knowing whether these children were sick any more often, or any more seriously, than the average child. Second, we do not know whether these trainees were any less willing than other parents to trust others with their sick children。

Children can worry their parents with more than just illness. A few parents named unspecified trouble with their children as pressing responsibilities. Presumably, some shildren may have had behavioral or emotional problems that demanded too much parental attention to allow the trainee to continue in class.

Although children were the most typical family members who needed attention, they were not the only ones. A few students dropped out for other reasons of "family health," such as caring for a sick mother or injured husband.

Health

An even more commonly mentioned problem (in 39 cases) was the student's own health. In some cases, serious illness, such as pneumonia, operations or other hospitalization, or injuries from accidents kept the client from attending classes. As in some family care cases, health problems sometimes interrupted training often enough to make catching up infeasible, leading the trainee to drop out.

Other clients who reportedly quit training because of poor health seemed to have less severe problems, however, such as "not feeling well" during pregnancy, or other unspecified illness. It is impossible to 
45

judge another person's feelings of physical well-being. It has been remarked, however, that a person who feels generally happy and satisfied with his or her work or schooling is more likely to minimize the interru-ptions or illness than someone who is basically dissatisfied or ambivalent about his activities. The subjective importance of sickness may be a factor in some cases.

Transportation

Thirteen trainees said they had trouble getting to class because of transportation difficulties. In a few cases this took the form of "car trouble." Logically, the complaint was more prominent where students had longer distances to travel; a major example was a boatbuilding class in Warren which was apparently inaccessible to a few students。

Other Personal Reasons

Other personal problems were responsible for some clients' leaving the program. For example, a spouse's drinking problem, or trouble with a girlfriend, were insurmountable obstacles for two trainees. Other causes were less specific, with "problems at home" or"personal reasons" or "depression" or other psychological problems given as reasons for discontinuing. A small number of clients became entangled in legal problems which contributed to poor attendance.

Another kind of personal problems, noted in 36 cases, was the behavioral, attitudinal, or social difficulties that were noticeable in some students. These can be roughly divided into two types, which occasionally overlapped.

Some students were described as having "attitude problems," or 
judge another person's feelings of physical well-being. It has been remarked, however, that a person who feels generally happy and satisfied with his or her work or schooling is more likely to minimize the interru-ptions or illness than someone who is basically dissatisfied or ambivalent about his activities. The subjective importance of sickness may be a factor in some cases.

Transportation

Thirteen trainees said they had trouble getting to class because of transportation difficulties. In a few cases this took the form of "car trouble." Logically, the complaint was more prominent where students had longer distances to travel; a major example was a boatbuilding class in Warren which was apparently inaccessible to a few students.

\section{Other Personal Reasons}

Other personal problems were responsible for some clients' leaving the program. For example, a spouse's drinking problem, or trouble with a girlfriend, were insurmountable obstacles for two trainees. Other causes were less specific, with "problems at home" or"personal reasons" or "depression" or other psychological problems given as reasons for discontinuing. A small number of clients became entangled in legal problems which contributed to poor attendance.

Another kind of personal problems, noted in 36 cases, was the behavioral, attitudinal, or social difficulties that were noticeable in some students. These can be roughly divided into two types, which occasionally overlapped.

Some students were described as having "attitude problems," or 
aggressive or disruptive behavior, ranging from childish "outbursts" in class, a "temperamental" disposition, or a "chip on her shoulder," to theft or outright dangerous confrontations with other students or the instructor. Clearly, such poorly adjusted social skills were an impediment to the training process itself, marring the learning environment for the other class members as well as for the individual in question. Although in two or three cases the student managed to improve his or her conduct, following poor evaluations and warnings, most were terminated in the "administrative separation" category.

On the other end of the behavioral spectrum were enrollees who were not aggressive enough, but were shy, quiet, nervous, or lacking in self-confidence. Although this kind of trainee might feel comfortable enough to succeed in a classroom situation, he or she might have more trouble being hired for a job, as a counselor noted in calling a trainee a "poor candidate" because of her shyness. All of these students either "refused to continue" or could not be placed.

It is important to point out that trainees who had one obstacle to overcome often had others, as well. A few had to cope with both their own poor health and that of their children, for example. Sometimes there were multiple issues contributing to excessive absence or outright quitting: car problems, involvement in court, and family sickness, for example. It is easy to imagine the discouragement of such a situation. However, the way that a person deals with problems can have as much of an impact as the problems themselves.

PROBLEMS WITHIN THE PROGRAM

Problems that related to the client's involvement in OIC can be 
subdivided into three varieties. Some trainees lacked interest in the field for which they were training; a second group had complaints about the agency; and a third had difficulty doing the required coursework. Motivation Problems

The most common of these problems, noted in 26 cases, was a lack of interest in the subject the trainee was learning. In most cases, the instructor's evaluation simply recorded a "loss if interest" or lack of seriousness about training. Some clients discovered that they were not "cut out" for the field; two students in nursing assistance, for example, found themselves too emotionally upset by the vocation to continue. A small number found training boring because they had already had some experience in the area; since course material is designed to teach only entry level skills, this sould not be surprising.

Dissatisfaction with OIC

Most trainees appeared to have a positive feeling about OIC, considering personnel helpful and approachable. Few reported dissatisfaction with counselors in their answers to survey questions. Similarly, most of those who had been enrolled long enough to have substantial contact with a job developer looked upon them favorably. A few people felt that job developers were not helpful enough to each individual in placement, or that they played favorites. Although dissatisfaction with a job developer could potentially contribute to discouragement during the placement phase of the program, it seems highly unlikely that it would cause a student to arop out before completion.

A somewhat larger number of trainees expressed displeasure with instructors, citing either a lack of serious teaching comittment ("too 
much fooling around in class," for example), favoritism, or turnover. There is also an indication that a shortage of equipment in at least one class put an undue strain on both the teachers and the students.

Academic Difficulty

Some students (23) professed a hard time doing the classwork, either in the skills training itself or remedial classes (training-related education (TRE) or ESL, English as a second language)。 Although more than one student had trouble in the skill itself - for example, poor spatial comprehension in a machinist course, or poor manual dexterity for an office helper trainee - the problem of weak basic skills crops up more often. Several students had trouble with math needed for their training, and a few, including Hispanics and other non-native English speakers, were impeded by poor English and language sikills.

\section{PLACEMENT}

The question of program outcome does not end with program completion. After finishing training, some fifteen of these individuals went out on interviews - some went out on several - but were not hired. Thirteen either refused to go on interviews, or did not keep scheduled appointments. Fifteen were hired but either refused work or did not show up for the job. Most of the completers probably dropped out for the same reasons as non-completers. Only two refused jobs because they paid insufficient wages, and only one would not take a job because of inconvenient work hours. Others appeared to be dissatisfied with the job itself, in some cases after only a few hours on the job, and in other cases without trying it at all. 
CHAPTER V

SUMMARY AND CONCLUSIONS

Who drops out, and why? This final chapter summarizes the findings of the previous chapters, and adds some likely reasons for each. It also suggests several ways to help treat the problem.

\section{CLIENT SUBGROUPS}

As Chapter III described in detail, the firidings showed that certain groups of clients were more prone to drop out of the program than others. Participants ${ }^{\prime}$ family status, economic status, and ethnic group did influence their success or failure in the program. While a client's sex, age, or education level alone were poor indicators of program outcome, they were significant in some cases as subdividers of the first three characteristics.

Family Status

Heads of households were more likely to drop out than household "members" who were not primary wage-earners and individuals who lived alone. Since we would assume that heads of families have more economic pressure to improve their skills and get a job in order to support their dependents, this is, at first glance, an alarming finding.

However, it was female rather than male heads of household who had a large proportion of dropouts, and most of these women were on public assistance programs, notably AFDC。 This means that there was 
minimal urgency for finding a viable, well-paying job.

Women who head families, in fact, are probably under more pressure not to get a job. Most of them are undoubtedly single parents, with responsibilities at home which they consider too heavy to allow them to stay away for the whole workday. It is logical to conclude that a large number feel too burdened by problems such as child care and family health to continue to work outside their homes.

The problems of the single parent are complicated for many of them by their economic status.

Economic Status

Welfare recipients dropped out of the program significantly more often than those not receiving welfare. Again, the correlation of economic status with sex and family status is crucial here, since three quarters of assistance recipients were female heads of families.

However, the findings that the welfare population as a whole dropped out significantly more often than others on assistance, suggest that the subsidy in itself influences clients to quit the program. People on public assistance could economically afford to fall back on their payments if they stopped training.

In fact, the automatic cutbacks in public support when a family goes off public assistance is often considered a disincentive to working. The welfare mother who leaves the AFDC program, for example, also loses the food stamps and medical coverage that supplement the basic payments. She must weigh the loss of fringe benefits and the inconveniences of a daily job against a few dollors more per week plus the dubious pride of earning her own living. These disincentives, combined with the anxiety 
that many parents feel about leaving their children to day care centers or babysitters, evidently discourage people who are not extremely motivated.

Ethnic Group

Hispanics had the highest dropout rate of any of the ethnic groups, with blacks second, and whites lowest.

Part of this pattern may be explained by the family status composition of whites and Hispanics. Since less than a third of the whites were heads of families, their higher dropout rate did not strongly affect the dropout rate for all whites; Hispanics, on the other hand, who had a very high dropout rate among the more than half who headed households, were affected much more in their overall dropout rate. However, this limited explanation does not apply at all to the black population, whose heads of families dropped out less than other household members and singles.

The disparity among the three groups is perhaps due more to cultural differences than to other factors. For instance, attitudes towards the importance of the work ethic and long-term achievement may differ. There may also be variations in the resources of members of each group for supporting themselves outside of the mainstream labor market.

All of the client subgroups have been pointed out as having special problems. It is possible that, with special attention, their high dropout rates can be reduced.

General Aptitude Test Battery

The GATB had a limited value as an indicator of program outcome. As will be discussed later, the tests are sometimes not even used within their limits. 
The GATB was, however, a barometer of education level and ethnic group. High school graduates scored better than non-graduates. Blacks did better on the tests than Hispanics, and whites scored considerably higher than the other two. These relationships should be remembered when using the GATB.

PERSONAL REASONS FOR DROPPING OUT

\section{Child and Family Care}

The propensity of heads of families, especially women who are probably single parents, to drop out has already been discussed. Quite reasonably, one reason given by trainees for quitting was child care, especially when children were sick or had other problems.

Several explanations may account for the number of dropouts for family care reasons. First, the style of support given by OIC may not be enough for these clients. Self-help, in fact, is becoming more and more the philosophy of OIC support services. Reasoning that an employee on the job will have to fend for him/herself in problem-solving, the agency tries to begin the process in the training situation. Hand-holding falls more and more out of favor. Although self-help is an understandable and laudable goal, some trainees may have needed more direct help at this stage. Even when they are taught how to go about finding child care service during orientation, and as the need arises, certain individuals may not be motivated enough to take action.

Second, some students might have used child care problems as a good, concrete excuse for quitting when they really had more nebulous reasons. In other words, they may have felt that they had to have some valid explanation ready for their counselors and other personnel. 
Third, for a variety of reasons, there may have been an unusual amount of sickness among the families of these students, requiring more attention than a babysitter or a day care center could provide.

Finally, these parents may have felt more social pressure to be at home with their children, especially when they were ill; or they may simply have preferred staying with their children to going to the training classes.

An arrangement for part-time training, as well as for part-time jobs, could be a viable compromise for some parents. At present, neither is permitted under CETA regulations; only full-time employment counts as placement. The popularity of nursing assistance training, which has been discontinued, may support this theory: despite its low pay scale, nursing assistance attracts workers with its considerable flexibility in work hours as well as many opportunities for part-time employment.

Health

A student's own health was another common reason given for discontinuing training.

As with child care problems, this is not an altogether clearcut issue. Of course, a certain amount of attrition because of serious illness is inevitable in any population. Again, however, several explanations are feasible. Poor health may have been an objective reality in this disadvantaged population. In this case, the second question is how much bad health could have been avoided through preventative measures. A second possibility is that sickness was subjectively more debilitating to these clients. That is, finding themselves only moderately interested in their daily activities, or with 
ambivalent feelings, they may have allowed illness to take on an importance which it would not have had if they had been more enthusiastic about staying in training. Third, bad health may have been a convenient excuse for some students who wanted to drop out.

Poor Social Skills

Some students had a difficult time either in the program or in being placed because they had behavioral or attitudinal problems. Some clients disrupted the training process for themselves and others by having open conflicts with their instructors or other students. Resentful or belligerent attitudes and behavior are probably too deeply ingrained for quick and easy solutions, though they could perhaps be alleviated with professional counseling in some cases. In many instances, however, administrative separation would be the only way to do justice to the other members of the class.

Trainees who were too shy or unsure of themselves also had trouble, especially in being placed. Again, professional counseling might benefit some of these individuals.

\section{Multiple Problems}

A number of students dropped out because of more than one problem. Faced with a combination of obstacles in family care, health, transportation, legal, or other personal issues, a student was even more likely to miss too many classes to continue the program, and to be discouraged to the point of giving up.

However, the condition of "having problems" cannot be considered an isolation. Clearly, some people are better prepared than others to cope with adversity. Many of the "disadvantaged" are also at a 
disadvantage in this sense. Not only do they have more problems to deal with - an old car breaks down more often than a new one, for example; and medical and legal help is more complicated and tedious to come by for the poor - but frequently they also have less information, education, and even confidence to solve them. While OIC's support services do not have the power to eliminate the problems themselves, they can be valuable in helping clients to manage their own lives better by supplying information and referrals, counseling and intervention, to begin to teach them techniques to help themselves.

As in the matter of child care, however, it is possible that the agency ${ }^{\circ}$ s support services do not go far enough to aid its clients. A philosophical choice is involved. On one had, an extreme orientation towards self-help may effectively prepare students for the post-training situation in which no nurturing hand is available. (OIC tries to simulate the real work world through its other policies, such as strict rules on absences, too.) In this case, clients either sink or swim, and the most able are the ones to benefit most from the program and have the best chances when they enter employment. The other choice is to offer more directive counseling and support services which will heighten the probability that weaker candidates will complete the program successfully. A gradual and deliberate transition from directive to self-help-oriented services could increase the clients' chances of success in unsubsidized employment.

PROBLEMS WITH THE PROGRAM

Motivation

Some students discovered that they were not interested in, or 
not suited to, the field that they were learning. The CETA intake system undoubtedly accounts for a portion of motivational problems.

As Chapter III mentioned, the course in which a student enrolls is frequently determined not by his or her preference - in fact, many applicants may not know themselves what kind of work they would enjoy or by aptidude, so much as by the courses beginning at the time the individual applies. In some cases, clients who applied for particular classes were directed towards another kind of training when their first choice was filled to capacity or unavailable. In this situation, obviously, the GATB is not being used even to its limited capacity。 In autobiographies and goal statements, clients repeatedly expressed their desire to "improve" themselves or to "make something" of themselves, or to get off welfare. Still, although clients may be motivated in the sense of wanting overall self-improvement, they often have no special enthusiasm for the specific training in which they find themselves.

Two possible solutions suggest themselves, both out of OIC's hands. One is to administer occupational preference tests during the intake process to help match applicants with suitable training。 Another is to provide transitional programs or some other incentive for candidates who must wait for an opening in their preferred field of instruction. Both services could cut down the number of students who quit the program out of a lack of interest.

Academic Problems

Difficulty with required coursework contributed to discontinuing training in some cases. The most typically troublesome areas were math 
and language skills.

Students who score low in GATB exams are required to take training related education (TRE) along with their regular coursework. TRE is designed precisely to improve basic skills in math and English which are needed in their classes. However, TRE classes are offered for only one hour a day, during the training period. Evidently, this limited offering is insufficient for some students.

One alternative might be to offer some clients more intensive remedial education before the regular training begins, as well as the supplementary five hours per week during training. This could improve their capacity to make use of the vocational training and keep up with others in the class.

Classes in printing and drafting may cause special problems. This type of training had the highest proportion of dropouts, and was the only one in which the clients" level of education and scores on the relevant aptitude tests made a significant difference in performance. It has been suggested that technical requirements such as precise measurement skills are needed more for this type of training than for others. In this case more supplementary training may be called for.

Dissatisfaction with the Agency

Dissatisfaction with OIC's instructors, counselors, and job deveopers did not show up as major issues. Of the three, instructors were criticized most often.

In some cases, conflict between students and instructors probably occurred because of problems on both sides - that is, a few students 
who were unhappy with teachers were probably causing at least part of the trouble themselves. In at least one case, a student complained of a shortage of teachers, and in another an apparently poor teacher was replaced by a more satisfactory substitute. Obviously, OIC must do its best to hire competent and committed instructors. In fact, teachers who do not meet this standard appear to be the exception rather than the rule at OIC.

A shortage of equipment which was reported more than once can seriously cripple some training. The agency, of course, furnishes adequate training equipment for its student population to the extent of its funding capacity.

PLACEMENT

Several factors made OIC "unable to place" some training graduates.

In some cases, the clients themselves affected their likelihood of being hired. Those who were shy, nervous, or who did "not come across well in interviews", and those who were less qualified according to the job developer's assessment were probably at a disadvantage in the placement phase of the program。

As the introduction pointed out, some employers mistrust CETA graduates, and are "unlikely to believe that (the most qualified) applicants will be found on CETA rolls."1 They expect CETA trainees to be less qualified, less motivated, and less likely to stay on the job than graduates of private institutions. This is sometimes the case with OIC. A potential employer who has had bad experiences with OIC or other CETA placements is often unwilling to try again.

1 U.S. Department of Labor, Employment and Training Administration, "GETA Prime Sponsor Management Decisions and Program Goal Achievement," R\&D Monograph 56, 1978, p.38. 
An OIG graduate who quits a job or performs poorly may be viewed as representative of the program as a whole, while successful placements are forgotten. Employers who have had no contact with OIC may be under the impression that many of its clients are misfits, such as arug addicts or ex-convicts, and refuse contact for this reason. Finally, remembering that a majority of OIC's population is from minority groups, one cannot discount discrimination as a deterrent.

Classes in the office occupations had the highest percentage of trainees who could not be placed. Job developers attribute this fact to sheer numbers, rather than to characteristics of the labor market. In fact, the clerical classes in the 1979 population examined here had one and a half times as many students as machine trades, over three times as many as printing and drafting, and over four times as many as in nursing classes.

CETA regulations also restrict placement. One reason is that many employers have begun to use private employment agencies, which screen out most job applicants and send along only the most highly qualified. OIC, of course, screens out only the least qualified from its programs. Also, OIC cannot send its graduates through the private agencies for employment; graduates must be placed directly from OIC into a job to technically qualify as CETA "placements."

A more important constraint of CETA regulations is the time limit they set on placement. OIC must place the student after he or she has completed 85 or 90 percent (depending on type of training) of the course, and within 30 days of the end of the class. Although it is not difficult to obtain administrative approval for early placement, a trainee must still be on the job during the week following the end 
of the course to be counted as "placed." These rules can impose difficult decisions on OIC job developers, who sometimes feel they must forego high quality placements before or after the allotted time period, in order to meet placement goals.

A job training organization like OIC will always have dropouts。 Some clients do have insurmountable problems. Some are not serious enough about training; some agency staff members suspect that many participants who are happy to have a place to go in the winter are happier to drop out in the spring. The stipend that CETA pays enrollees is a grand incentive to many people who are not especially motivated to get a regular job. Empirical evidence has indicated that problems with socialization, or the work ethic, which is a primary barrier to entry level jobs, are exactly the qualities most difficult to transmit in employment training programs. ${ }^{1}$ Finally, operating within CETA regulations is in some ways a handicap.

Nevertheless, OIC should be able to cut its dropout rate to some extent。 By being attentive to the client groups with the most problems, and by taking measures to counteract the most common difficulties, the agency could achieve a goal of heightened success.

1 Lester C. Thurow, "Redistributional Aspects of Manpower Training Programs," Manpower Programs in the Policy Mix, ed. Lloyd Ulman, (Baltimore: The Johns Hopkins University Press, 1973), p. 90. 
BIBLIOGRAPHY

$\underline{\text { Books }}$

Everitt, B.S. The Analysis of Contingency Tables. London: Chapman and Hall, 1977.

Frieden, Bernard J., and Robert Morris. Urban Planning and Social Policy.

New York: Basic Books, Inc., 1976。

Levitan, Sar A., Mangum, Garth L., and Marshall, Ray. Human Resources and Labor Markets. New York: Harper and Row, Publishers, 1976.

Mangum, Garth L., and Robson, R. Thayne. Metropolitan Impact of Manpower Programs: A Four-City Comparison. Salt Lake City: Olympus Publishing Company, 1973.

Mirengoff, William and Rindler, Lester. CETA: Manpower Programs Under Local Control. Washington, D.C.: National Academy of Sciences, 1978.

The Research and Policy Committee of the Committee for Economic Development. Jobs for the Hard-to-Employ - New Directions For a Public-Private Partnership. New York: The Committee For Economic Development, 1978.

Ulman, Lloyd (ed.). Manpower Programs in the Policy Mix. Baltimore: The Johns Hopkins University Press, 1973.

Wolfbein, Seymour L. (ed.). Manpower Policy: Perspectives and Prospects. Philadelphia: Temple University School of Business Administration, 1973.

\section{Public Documents}

U.S. Department of Labor, Employment and Training Administration. CETA Prime Sponsor Management and Program Goal Achievement. R\&D Monograph 56, 1978.

U.S. Department of Labor, Employment and Training Administration, and U.S. Department of Health, Education and Welfare. Employment and Training Report of the President. 1978.

U.S. Department of Labor, Bureau of Employment Security. General Aptitude Test Battery. Section III, 1962.

U.S. Department of Labor, Employment and Training Administration, Office of Policy, Evaluation and Research, and MDC, Inc. How to Get Started on Evaluation: A Field Report and Guide For CETA Prime Sponsors. 1977.

U.S. Department of Labor, Employment and Training Administration. The Implementation of CETA in Eastern Massachusetts and Boston. R\&D Monograph 57, 1978. - The Implementation of CETA in Ohio. R\&D Monograph 44, 1977. 


\section{Articles and Periodicals}

Providence Journal. July 27, 1978, p.A3。

Salipante, Paul, Jr., and Goodman, Paul. "Training, Counseling, and Retention of the Hard-Core Unemployed," Journal of Applied Psychology, Vol. 61 (February, 1976), pp.1-11.

Sawhney, Pawan K., et al. "Selected Findings of a Follow-Up Survey of CETA Title I Institutional Skill Training Programs in Boston," The New England Journal of Business and Economics, Vol. 5, No.1 (Fall 1978), pp. 76-95.

U.S. Department of Labor, Employment and Training Administration. "Comprehensive Employment and Training Act. Proposed Rules For Programs Under Titles I,II,VI, and VIII of the Act," Federal Register, Vol. 44, No. 14, Part IX。 (January 19, 1979)。

\section{Unpublished Material}

Kobrin, Frances E., Follow-up Evaluation Project for Providence CETA Administration. Unpublished interim report, January, 1980

Providence CETA Prime Sponsor. Management Information System. October, 1979. 
APPENDIX

O.I.C. FOLLOW-UP

QUESTIONNAIRE

NAME:

Questions 1 through 7 and question 22 pertained

to present employment status, and were not used

for the analysis in this paper.)

8. We understand that you participated in training while at O.I.C. What did you expect to get out of the program in terms of job skills?

9. Did you feel that you were getting the skills that you expected? Why or wny not.

10. What kind of job did you expect to be qualified for at the end of training?

11. Did you feel that you were getting prepared for that kind of job? Why or why not.

12. Did you find the training difficult? Explain the difficulties or problems you had.

13. Did you feel free to discuss any problems that you were having with the training with your instructor? Explain their helpful or unhelpfulness.

14. How often did you meet with the counselor?

15. Was the counselor available when you needed his/her help?

16. Were they helpful? How?

17. After you decided to leave the program did you contact your counselor?

18. How often did you meet with the job developer?

19. Was he/she helpful in trying to find you a job?

20. Did the job developer give you an idea of the kind of jobs available in your skill area?

21. What made you decide to leave O.I.C. before getting a job? 